\title{
Transformation-induced stress at telomeres is counteracted through changes in the telomeric proteome including SAMHD1
}

\author{
Jana Majerska ${ }^{1,2}$, Marianna Feretzaki ${ }^{1,2}$, Galina Glousker ${ }^{1,2}$, Joachim Lingner ${ }^{1,2}$ (D)
}

\begin{abstract}
Telomeres play crucial roles during tumorigenesis, inducing cellular senescence upon telomere shortening and extensive chromosome instability during telomere crisis. However, it has not been investigated if and how cellular transformation and oncogenic stress alter telomeric chromatin composition and function. Here, we transform human fibroblasts by consecutive transduction with vectors expressing hTERT, the SV40 early region, and activated H-RasV12. Pairwise comparisons of the telomeric proteome during different stages of transformation reveal up-regulation of proteins involved in chromatin remodeling, DNA repair, and replication at chromosome ends. Depletion of several of these proteins induces telomere fragility, indicating their roles in replication of telomeric DNA. Depletion of SAMHD1, which has reported roles in DNA resection and homology-directed repair, leads to telomere breakage events in cells deprived of the shelterin component TRF1. Thus, our analysis identifies factors, which accumulate at telomeres during cellular transformation to promote telomere replication and repair, resisting oncogeneborne telomere replication stress.
\end{abstract}

DOI 10.26508/Isa.201800121 | Received 2 July 2018 | Revised 4 July 2018 | Accepted 5 July 2018 | Published online 17 July 2018

\section{Introduction}

Telomeres play critical roles in the progression of human cancer (Maciejowski \& de Lange, 2017). Most somatic cells in the human body do not express telomerase (Kim et al, 1994). Therefore, telomeres shorten with every round of DNA replication because of the end replication problem and the nucleolytic processing of chromosome ends (Soudet et al, 2014) by approximately 50-100 bp. Upon reaching a critically short length, telomeres elicit a DNA damage response (DDR) involving the DNA checkpoint protein kinases ATM and ATR (d'Adda di Fagagna et al, 2003; Denchi \& de Lange, 2007). The telomeric DDR induces permanent cell cycle arrest referred to as cellular senescence with a G1 DNA content. This block to proliferation of precancerous cells can be prevented through inactivation of the p53 and RB tumor suppressors (Shay \& Wright, 2005). Cells that bypass cellular senescence will hit telomere crisis during which telomeres lose their protective roles from end-to-end chromosome fusions by classical and alternative nonhomologous end joining (Jones et al, 2014). Thus, telomere crisis leads to chromosome fusions, mitotic missegregation, and chromosome breakage events that give rise to extensive chromosome instability. In cancer, telomere crisis is mostly overcome through up-regulation of the telomerase catalytic subunit hTERT, which frequently involves mutations in the hTERT promoter (Horn et al, 2013; Huang et al, 2013). Thus, telomerase becomes active, stabilizing telomere length of partially rearranged chromosomes.

In addition to gradual telomere shortening induced by the lack of telomerase, telomeres can be damaged and lost because of stochastic replication defects occurring during semiconservative replication of telomeric DNA (Miller et al, 2006; Chang et al, 2007; Sfeir et al, 2009). Telomere replication defects can give rise to a fragile phenotype, which is characterized by discontinuities in the telomeric signal detected on metaphase chromosome spreads (Sfeir et al, 2009). Telomeres are difficult to replicate and fragile for at least four reasons. First, the single-stranded TTAGGG repeat (G-rich)-containing strand may adopt highly stable G-quadruplex structures that need to be unwound to serve as a template during replication (Sfeir et al, 2009; Paeschke et al, 2011; Vannier et al, 2012). Second, telomeres can fold into t-loop structures in which the telomeric $3^{\prime}$ overhang is tucked into the double-stranded part of the telomere which need to be unwound during replication (Vannier et al, 2012; Doksani et al, 2013). Third, telomeres are transcribed into the long noncoding RNA TERRA that can form DNA/ RNA hybrid structures and as such can interfere with replication (Balk et al, 2013; Pfeiffer et al, 2013; Sagie et al, 2017). Fourth, telomere replication is driven from origins of replication that are present in the subtelomeric DNA. Origin firing occurs only rarely from within telomeric repeat sequences (Drosopoulos et al, 2015). Therefore, telomere replication is unidirectional and stalled forks may not be rescued from converging forks coming from the end of

${ }^{1}$ School of Life Sciences, Ecole Polytechnique Fédérale de Lausanne, Lausanne, Switzerland ${ }^{2}$ Swiss Institute for Experimental Cancer Research, Ecole Polytechnique Fédérale de Lausanne, Lausanne, Switzerland

Correspondence: joachim.lingner@epfl.ch 
the chromosome. Telomere fragility may become particularly pronounced during oncogenic transformation. Oncogene-induced hyperproliferation leads to replication stress, causing DNA damage at telomeres and elsewhere in the genome leading to cellular senescence (Bartkova et al, 2006; Di Micco et al, 2006; Suram et al, 2012). Remarkably, oncogene-induced damage at telomeres appears to persist, enforcing oncogene-induced cellular senescence (Fumagalli et al, 2012).

Despite the extensive knowledge on the critical roles of telomere length for cellular senescence and telomere crisis during carcinogenesis, very little is known about changes in telomeric protein components that occur during transformation. The telomerase catalytic subunit hTERT, which associates with telomeres during extension, is a notable exception having well-described key roles to allow cell immortality of cancer cells (Bodnar et al, 1998). In addition, mutations affecting the single-strand telomeric DNA-binding protein POT1 have been reported in a range of malignancies (Quesada et al, 2013; Ramsay et al, 2013; Robles-Espinoza et al, 2014; Calvete et al, 2015). However, a systematic analysis of the telomeric proteome during transformation is missing.

Here, we exploit the established in vitro transformation protocol of Hahn and Weinberg (Hahn et al, 1999, 2002) for oncogenic transformation of human lung fibroblasts (HLFs) by introducing defined genetic elements. We apply the previously developed quantitative telomeric chromatin isolation protocol (QTIP) (Grolimund et al, 2013; Majerska et al, 2017) to compare the telomeric proteomes during different stages of transformation. The telomeric proteome changes most notably upon transduction with the SV40 early region expressing the large $T$ and small $t$ antigens inhibiting p53 and the protein phosphatase $2 \mathrm{~A}$, respectively. Up-regulated telomeric proteins include factors that safeguard telomeres from fragility and, therefore, may suppress oncogene-induced replication stress and senescence. We also discover a crucial function for SAM domain and HD domain-containing protein 1 (SAMHD1), which counteracts telomere breakage events in cells depleted of telomere repeat-binding factor 1 (TRF1).

\section{Results}

\section{Experimental system to study the telomeric proteome during transformation}

We transformed HLFs (Ducrest et al, 2001) using the following consecutive steps. First, HLFs were transduced with a retroviral vector containing the hTERT cDNA. Thus, HLFs expressed active telomerase, stabilized their telomere length around $13 \mathrm{~kb}$ (Fig S1), and became immortal. These cells are referred to as HLF-T. Second, we transduced the HLF-T with retrovirus expressing the SV40 early region, encoding large $T$ and small $t$ antigens. These cells, referred to as HLF-TS suppressed p53 and RB function via large $T$ and phosphatase $2 \mathrm{~A}$ via small $t$ antigens (Hahn et al, 2002). In a final step, HLF-TS cells were transduced with retrovirus containing the $\mathrm{H}$-RasV12 allele, which is a constitutively active version of the H-Ras GTPase, stimulating uncontrolled cell growth in the absence of external signals. These cells were referred to as HLF-TSR. Upon large-scale cell expansion, HLF-T, HLF-TS, and HLF-TSR were indistinguishable with regard to their telomere length, whereas the telomeres in HLFs with inactive telomerase were markedly shorter (Fig S1), because of progressive telomere attrition (Cristofari \& Lingner, 2006).

We compared the telomeric protein composition of the four HLF cell lines by QTIP (Grolimund et al, 2013; Majerska et al, 2017) in a pairwise fashion (Fig 1A). Briefly, cells to be compared were grown in different SILAC (stable isotope labeling by amino acids in cell culture; Ong et al, 2002) media to distinguish identical proteins from the pair of cells by their mass and be able to identify quantitative differences in telomere protein abundance. Cell populations to be compared were mixed (Fig 1B) and cross-linked with formaldehyde and ethylene glycol bis(succinimidyl succinate). Chromatin was sonicated and telomeric chromatin isolated using antibodies against the abundant telomeric proteins TRF1 and TRF2. Protein amounts were compared by LC-MS/MS. Replicates were done in which the heavy and light SILAC media were swapped between the two cell populations (Fig S2). The recovery of telomeric DNA was approximately $5-10 \%$ and the enrichment of telomeric DNA over Alu repeat DNA around 300-fold (Figs 1C and S3). The spectral counts of shelterin proteins obtained with TRF1/TRF2 antibodies varied from roughly 50 for POT1 and TPP1 to more than 500 for TRF2 (Fig 1D). Shelterin proteins were completely absent from control IgG pulldowns, confirming highest specificity of the purification. Proteins were considered as putatively telomeric when their spectral counts obtained with TRF1/2 antibodies over those obtained with IgG were significantly higher in at least two of the four QTIPs using a Significance A left-sided test $(P<0.05) .134$ proteins passed the filtration criteria (Table S1). The identified proteins overlapped partially with proteins that were identified in previous telomeric proteomic screens (Dejardin \& Kingston, 2009; Grolimund et al, 2013; Bartocci et al, 2014). These include most prominently the six shelterin proteins but also proteins involved in DNA replication (MCM4, MCM5, and MCM7), repair and end processing (RAD50; Apollo), chromatin remodeling (SMCHD1), and RNA processing (TCEA1) (Fig 2A). In addition, several new telomeric protein candidates were discovered in HLFs. To test their association with telomeric DNA, we expressed selected candidates (Fig 2B) as 3xHA-tagged proteins upon transient transfection in HEK293T cells and tested association with telomeric DNA and Alu repeat DNA by chromatin immunoprecipitation (ChIP) via the HA tags (Figs $2 \mathrm{C}$ and S4). HA-tagged CLP1, PNUTS, SAMHD1, ARHGAP1, and TCEA1 all immunoprecipitated with the anti-HA antibody significantly more telomeric DNA than the empty vector control, indicating that they are genuine telomere-associated proteins. The considerably lower but detectable association with Alu repeat DNA suggested association also with other regions of the genome.

\section{Identification of telomeric proteins that change during transformation}

The four comparisons by QTIP (Fig 1B) identified 39 telomeric factors that became either up- or down-regulated during different steps of transformation (Figs 3 and S5, and Table 1). The most notable differences induced during transformation could be ascribed to expression of the SV40 early region. Several proteins involved in DNA replication, DDR, and DNA repair became up-regulated at telomeres upon expression of the T antigens. H-RasV12 expression 


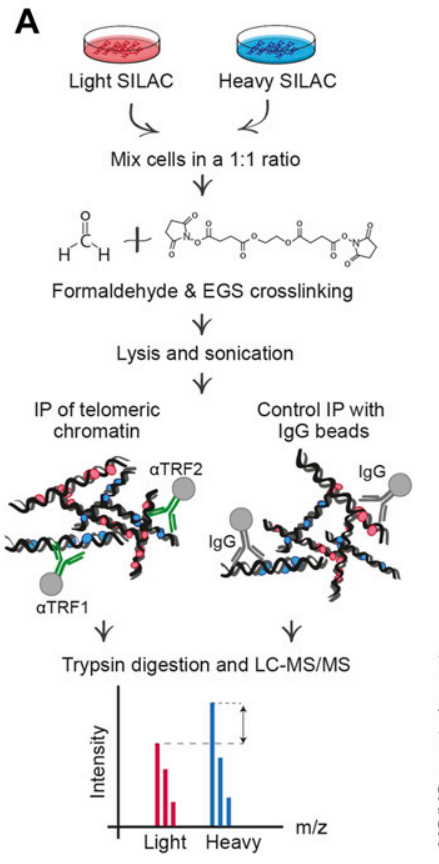

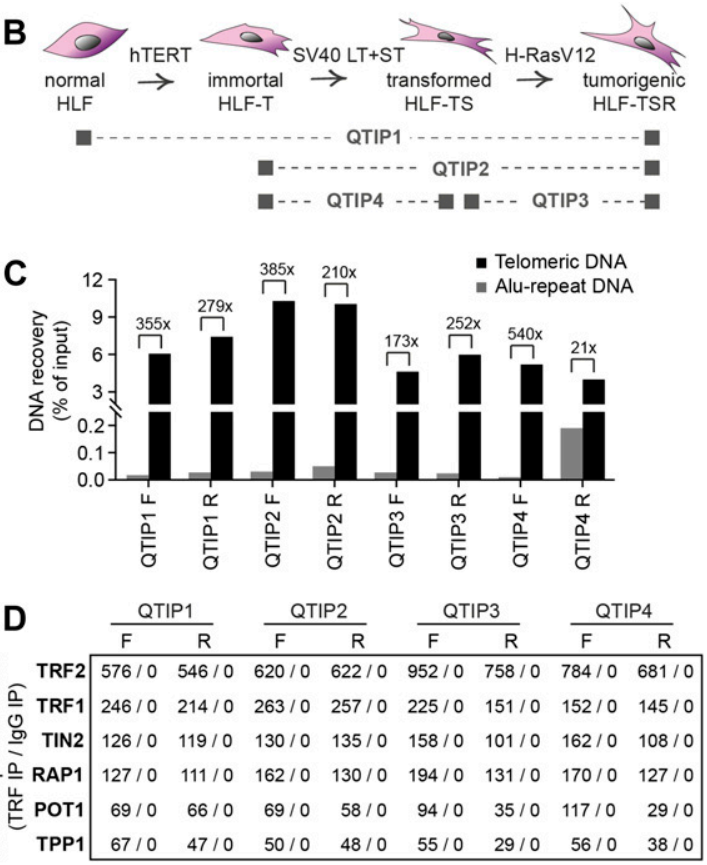

Figure 1. QTIP method was used to characterize changes in telomere protein composition during cellular transformation.

(A) Workflow of QTIP. (B) Schematic of the cell line model and overview of the four pairwise QTIP experiments. HLFs were serially transduced with retroviral vectors expressing hTERT, the SV40 large T (LT) and small t (ST) antigens, and H-RasV12. (C) Quantification of precipitated DNA in QTIPs, based on a dot blot hybridized with a specific telomeric probe and a control Alu repeat probe (Fig S3). To determine IP efficiency, the amounts of telomeric DNA in QTIP eluates were quantified and compared with the telomeric DNA in inputs. Fold enrichment of precipitated telomeric DNA compared with precipitated Alu repeat DNA is used as an indicator of IP specificity. Plotted are values from the forward (F) and reverse (R) TRF IP replicates. (D) Enrichment of shelterin subunits in QTIPS. The mean of spectral counts of two replicates is indicated. was associated with milder alterations and contributed to downregulation of a small subset of proteins of as-yet-unknown telomeric function. In some cases, H-RasV12 slightly counteracted the effect of SV40 T antigens (Fig 3B). The transformation-induced changes did not depend on telomere length because the comparison of HLF-TSR with either HLF or HLF-T cells yielded similar results. Cell transformation also increased the levels of shelterin components TRF1, TRF2, and its interacting protein RAP1, whereas TIN2, TPP1, and POT1 did not change (Figs 3 and S5). Up-regulation of TRF2 was confirmed on Western blots (Fig S6A) and is consistent with previous reports of increased TRF1
A

Shelterin

TRF1, TRF2, RAP1, TIN2, TPP1, POT1

DNA replication

MCM4,5,7, ORC1, ORC3, ORC5, POLDIP2

DNA damage and repair

p53, Apollo, SAMHD1, RAD50, PARP9, DTX3L, MORC3, SPTAN1

Transcription and RNA processing

- POLR1A, POLR2B, PAF1, CDC73, TCEA1, THOC6, THRAP3, CLP1, PRPF40A, PCF11, CPSF2, CSTF1, U2AF1, TXNL4A, SF1, KHSRP, UPF2, EIF4E, METTL16

- BCLAF1, CTNND1, FOXJ3, FUBP3, HDGF, NPAT, HNRNPUL1, PHF3, ZNF609

- RBM14, RBM25, DAZAP1, DDX60L, VARS, GRSF1, RNMTL1, TRMT6, TRMT61A, TSEN54, CARS
Chromatin remodeling SMCHD1, MKI67, RUVBL1, RUVBL2

Cytoskeleton-binding proteins, cell adhesion, and Rho GTPase cycle

RAI14, CFL2, CEP170, INF2, ITGB1, KIF23, KIF2A MPRIP, PKP4, ARHGAP1, TRIOBP, PDLIM5, FHL1 CLSTN1

Post-translational protein modification WDR82, PPP1CB, PNUTS, CAND1, USP7, RNF213, TRIM21

Protein folding and proteostasis

ССТ3, ССТ6A, СCT7, TCP1, HSPA9, HSPB6, CLPX PCMT1, PCMT1, TXNDC9

Nuclear periphery

TPR, TMPO, TNPO3
B

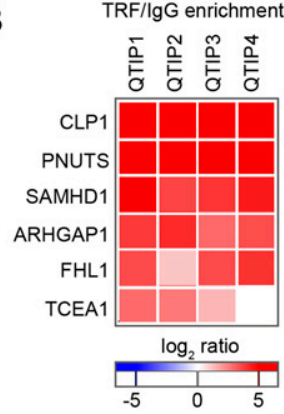

C

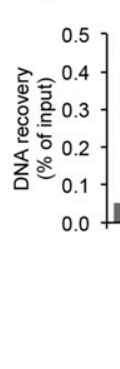

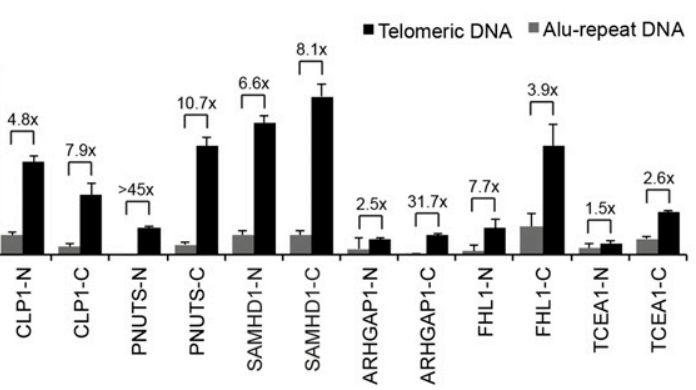

Figure 2. Telomeric proteome in human fibroblasts. (A) Overview of proteins with significant TRF/IgG enrichment in at least two of four QTIPS (Significance A left-sided test, $P<0.05$ ). The full protein list is in Table S1, list B. (B, C) Validation of telomeric localization of selected QTIP candidates by anti-HA ChIP against Nand C-terminally tagged proteins. The precipitated DNA was analyzed as described for Fig $1 C$. The background of empty vector control was subtracted. Plotted is mean + SD from two to three technical replicates. The images of dot blots are provided in Fig S4. 
A
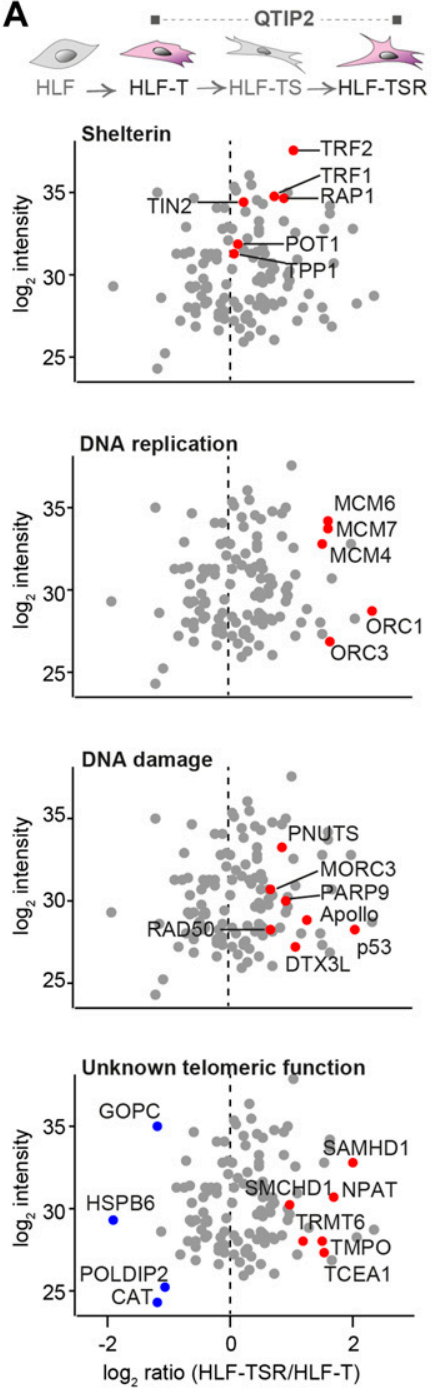

B
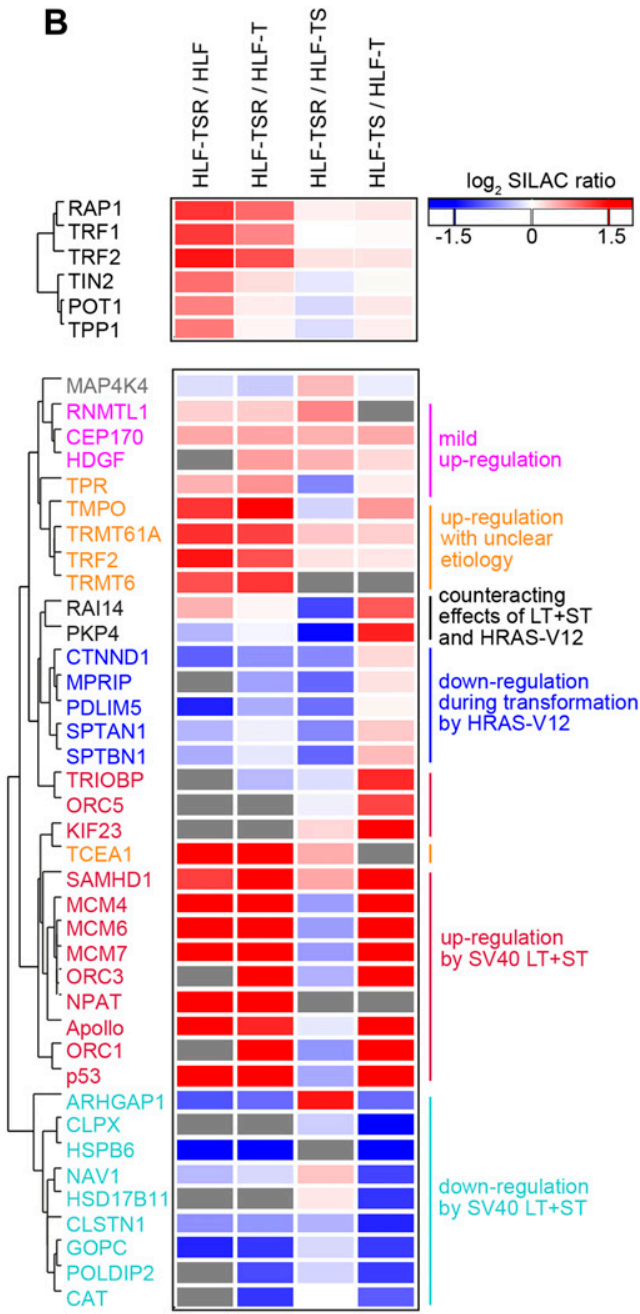

Figure 3. Identification of transformationresponsive telomeric proteins.

(A) Scatter plots for QTIP2 showing differences in telomere recruitment between HLF-T and HLF-TSR cell lines. Plotted are mean values from the forward and reverse TRF IP replicates. See also Fig S5. (B) Heatmap of differentially regulated telomeric proteins. Top panel: shelterin proteins; bottom panel: putative telomeric proteins that were significantly up-/down-regulated in TRF IP in at least one QTIP (Significance B, both sides, $P<0.05)$. Missing values are displayed in gray. and TRF2 expression in human malignancies (Nakanishi et al, 2003; Diehl et al, 2011; Pal et al, 2015; Chen et al, 2017). Overall, our analysis indicated that factors that preserve telomere integrity became upregulated during transformation. To further corroborate this notion, we analyzed the proteome of chromatin extracts of the four different HLF lines (Table S1). This analysis confirmed that factors which contribute to genome stability are up-regulated during transformation (Fig S6B), whereas the increase of phosphorylated ATM pS1981 and Chk2 pT68 indicated increased DNA damage (Fig S6A). The up-regulation of p53 with SV40 large T expression was expected as SV40 large T inactivates p53, preventing the up-regulation of the p53 target MDM2, which mediates p53 degradation in a negative feedback loop. Consistently, the p53 target p21 decreased upon transduction with SV40 large $\mathrm{T}$, suggesting efficient suppression of p53 function (Fig S6A). Overall, the analysis suggested that the increased DNA damage at telomeres and elsewhere in the genome, which may result from oncogene-induced replication stress and hyperproliferation (Fig S6C and D), is counteracted through SV40 T antigen-induced upregulation of proteins that contribute to DNA stability and repair.

\section{TERRA is up-regulated during cellular transformation}

The telomeric long noncoding RNA TERRA has been implicated among others in the telomeric DDR and the regulation of telomerase (Azzalin \& Lingner, 2015). In addition, TERRA can form RNA/ DNA hybrid structures at telomeres, which represent obstacles for the replication machinery (Balk et al, 2013; Pfeiffer et al, 2013) while promoting homology-directed repair (Arora et al, 2014; Graf et al, 2017). We measured overall TERRA levels on Northern blots (Fig 4A) and TERRA molecules stemming from specific chromosome ends by quantitative RT-PCR (RT-qPCR) (Feretzaki \& Lingner, 2017) (Fig 4B). This analysis revealed that the overall TERRA levels increased with every step of transformation. The analysis of individual TERRA molecules showed telomere endspecific regulation. TERRA stemming from telomeres $9 p$ and XpYp increased most notably upon transduction with hTERT, whereas $2 p$ TERRA increased upon transduction with the SV40 early region (Fig 4B). 15q, 17q, and 20q TERRA were not up-regulated during transformation. We also tested if the increased TERRA levels gave 


\section{Life Science Alliance}

Table 1. Transformation-responsive telomeric proteins identified by QTIP, reported functions, and association with cancer.

\begin{tabular}{|c|c|c|c|}
\hline Gene name & Major pathway & Canonical function & Cancer association \\
\hline APOA1 & Lipid metabolism & $\begin{array}{l}\text { Participates in cholesterol transport from tissues to } \\
\text { liver for excretion; roles in human sperm motility. }\end{array}$ & $\begin{array}{l}\text { (Wang et al, 2009; Su et al, 2010; van Duijnhoven et al, } \\
\text { 2011; Jiang et al, 2014; Zamanian-Daryoush \& } \\
\text { DiDonato, 2015) }\end{array}$ \\
\hline ARHGAP1 & Rho GTPase signaling & $\begin{array}{l}\text { GTPase activator for the Rho, Rac, and Cdc } 42 \\
\text { proteins. }\end{array}$ & (Ahn et al, 2012; Li et al, 2017) \\
\hline CAT & Antioxidant activity & Decomposition of hydrogen peroxide. & (Bauer, 2012; Glorieux et al, 2015; Wang et al, 2016) \\
\hline CEP170 & Microtubule dynamics & $\begin{array}{l}\text { Role in microtubule organization and cell } \\
\text { morphology. }\end{array}$ & Unknown \\
\hline CLPX & Proteostasis & $\begin{array}{l}\text { Component of the mitochondrial } \\
\text { unfoldase-peptidase complex. }\end{array}$ & Unknown (Seo et al, 2016) \\
\hline CLSTN1 & Intracellular transport & $\begin{array}{l}\text { Regulates kinesin-mediated cargo transport and } \\
\text { organizes microtubule polarity during axon } \\
\text { development. }\end{array}$ & Unknown \\
\hline CTNND1 & Cell adhesion, transcription & $\begin{array}{l}\text { Transcription regulation, cell adhesion, Wnt } \\
\text { signaling, and spatiotemporal control of small Rho- } \\
\text { GTPases. }\end{array}$ & $\begin{array}{l}\text { (Thoreson \& Reynolds, 2002; Dann et al, 2014; } \\
\text { Kourtidis et al, 2015; Li et al, 2015) }\end{array}$ \\
\hline $\begin{array}{l}\text { DCLRE1B } \\
\text { (Apollo) }\end{array}$ & $\begin{array}{l}\text { DNA repair, telomere } \\
\text { maintenance }\end{array}$ & $\begin{array}{l}5^{\prime}-3^{\prime} \text { exonuclease, control of DNA damage repair } \\
\text { and topological stress, generation and } \\
\text { maintenance of telomeric overhangs, and DNA } \\
\text { replication. }\end{array}$ & Unknown (Natrajan et al, 2007; Karami et al, 2016) \\
\hline GOPC & Proteostasis & Intracellular protein trafficking and degradation. & (Charest et al, 2003; Ohara et al, 2017) \\
\hline HDGF & Transcription regulation & $\begin{array}{l}\text { Heparin-binding protein with mitogenic activity. } \\
\text { Regulates transcription. }\end{array}$ & $\begin{array}{l}\text { (Hu et al, 2003; Chen et al, 2015; Lian et al, 2015; Wu } \\
\text { et al, 2016; Yang et al, 2016) }\end{array}$ \\
\hline HSD17B11 & Lipid metabolism & $\begin{array}{l}\text { Converts } 5 \alpha \text {-androstan- } 3 \alpha, 17 \beta \text {-diol to } \\
\text { androsterone. }\end{array}$ & (Nakamura et al, 2009) \\
\hline HSPB6 & Proteostasis & Acts as a molecular chaperone. & $\begin{array}{l}\text { (Noda et al, 2007; Matsushima-Nishiwaki et al, 2011, } \\
\text { 2016; Nagasawa et al, 2014; Qiao et al, 2014; Ju et al, } \\
\text { 2015) }\end{array}$ \\
\hline KIF23 & Cytokinesis & $\begin{array}{l}\text { Component of the centralspindlin complex, } \\
\text { essential for cytokinesis in Rho-mediated signaling. }\end{array}$ & $\begin{array}{l}\text { (Takahashi et al, 2012; Sun et al, 2015, 2016; Kato et al, } \\
\text { 2016) }\end{array}$ \\
\hline MAP4K4 & Protein kinase & $\begin{array}{l}\text { Activates several mitogen-activated protein kinase } \\
\text { pathways; involved in cancer cell growth, apoptosis, } \\
\text { and migration. }\end{array}$ & $\begin{array}{l}\text { (Qiu et al, 2012; Haas et al, 2013; Feng et al, 2016; Liu } \\
\text { et al, 2016; Gao et al, 2017) }\end{array}$ \\
\hline MCM4, 6, 7 & DNA replication & $\begin{array}{l}\text { Components of the MCM2-7 DNA replicative } \\
\text { helicase. }\end{array}$ & $\begin{array}{l}\text { (Honeycutt et al, 2006; Shima et al, 2007; Bagley et al, } \\
\text { 2012; Das et al, 2013; Kwok et al, 2015) }\end{array}$ \\
\hline MPRIP & Cytoskeleton regulation & $\begin{array}{l}\text { Targets myosin phosphatase to the actin } \\
\text { cytoskeleton. Regulation of the actin cytoskeleton } \\
\text { by RhoA and ROCK1. }\end{array}$ & (Ono et al, 2008) \\
\hline NAV1 & Cytoskeleton regulation & $\begin{array}{l}\text { Regulation of the microtubule cytoskeleton, } \\
\text { important for neuronal development, and interacts } \\
\text { with the RhoGEF TRIO. }\end{array}$ & Unknown \\
\hline NPAT & Transcription, cell cycle & $\begin{array}{l}\text { Required for progression through the } \mathrm{G} 1 \text { and } \mathrm{S} \\
\text { phases, for } \mathrm{S} \text { phase entry, and for activation of } \\
\text { histone gene transcription. }\end{array}$ & (Saarinen et al, 2011; Hamdi et al, 2017) \\
\hline ORC1, 3, 5 & DNA replication & $\begin{array}{l}\text { Components of the origin recognition complex; } \\
\text { required for the assembly of pre-RC. }\end{array}$ & Unknown (Champeris Tsaniras et al, 2014) \\
\hline PDLIM5 & Calcium signaling & $\begin{array}{l}\text { Regulates intracellular calcium levels by linking } \\
\text { calcium channel and PKC. }\end{array}$ & (Eeles et al, 2009; Kim et al, 2010) \\
\hline PKP4 & Cell adhesion & Regulates RhoA signaling during cytokinesis. & Unknown \\
\hline POLDIP2 & DNA replication and repair & $\begin{array}{l}\text { DNA replication and damage repair, also implicated } \\
\text { in mitochondrial function, extracellular matrix } \\
\text { regulation, cell cycle progression, focal adhesion, } \\
\text { and cell migration. }\end{array}$ & (Grinchuk et al, 2010; Chian et al, 2016) \\
\hline
\end{tabular}

(Continued on following page) 
Table 1. Continued

\begin{tabular}{|c|c|c|c|}
\hline Gene name & Major pathway & Canonical function & Cancer association \\
\hline RAl14 & Cytoskeleton regulation & $\begin{array}{l}\text { May have roles in human testis development and } \\
\text { spermatogenesis. }\end{array}$ & Unknown \\
\hline RNMTL1 & RNA processing & $\begin{array}{l}\text { Catalyses the formation of } 2^{\prime} \text {-o-methylguanosine at } \\
\text { position } 1370 \text { in the } 16 \mathrm{~S} \text { mitochondrial large- } \\
\text { subunit rRNA. }\end{array}$ & (Haiman et al, 2013) \\
\hline SAMHD1 & $\begin{array}{l}\text { dNTP and nucleic acid } \\
\text { metabolism }\end{array}$ & $\begin{array}{l}\text { dNTPase activity, has roles in DNA repair, innate } \\
\text { immunity, cancer, and HIV-1 restriction; } \\
\text { controversial nuclease activity. }\end{array}$ & $\begin{array}{l}\text { (Clifford et al, 2014; Shi et al, 2014; Wang et al, 2014; de } \\
\text { Silva et al, 2014; Merati et al, 2015; Rentoft et al, 2016) }\end{array}$ \\
\hline SPTAN1 & Regulation of cytoskeleton & $\begin{array}{l}\text { A scaffolding protein involved in cell adhesion and } \\
\text { motility; implicated in repair of DNA interstrand } \\
\text { cross-links. }\end{array}$ & $\begin{array}{l}\text { (Tuominen et al, 1996; Gorman et al, 2007; Cunha et al, } \\
\text { 2010; Wolgast et al, 2011; Hinrichsen et al, 2014) }\end{array}$ \\
\hline SPTBN1 & Regulation of cytoskeleton & $\begin{array}{l}\text { Scaffolding function in protein sorting, cell } \\
\text { adhesion, and migration; implicated in TGF- } \beta \\
\text { signaling. }\end{array}$ & $\begin{array}{l}\text { (Gorman et al, 2007; Jiang et al, 2010; Yao et al, 2010; } \\
\text { Zhi et al, 2015) }\end{array}$ \\
\hline TCEA1 & Transcription & $\begin{array}{l}\text { Required for efficient RNA polymerase } \| \\
\text { transcription elongation past template-encoded } \\
\text { arresting sites. }\end{array}$ & (Hubbard et al, 2008; Shema et al, 2011) \\
\hline TERF2 & Telomere maintenance & $\begin{array}{l}\text { Required for telomere capping and protection. } \\
\text { Inhibits nonhomologous end joining and ATM } \\
\text { activation at telomeres. Required for t loop } \\
\text { formation. }\end{array}$ & $\begin{array}{l}\text { (Nakanishi et al, 2003; Bellon et al, 2006; Munoz et al, } \\
\text { 2006; Diehl et al, 2011; Biroccio et al, 2013; Pal et al, } \\
\text { 2015; Chen et al, 2017) }\end{array}$ \\
\hline TMPO & Nuclear architecture & $\begin{array}{l}\text { Involved in the structural organization of the } \\
\text { nucleus and in the post-mitotic nuclear assembly. }\end{array}$ & (Brachner \& Foisner, 2014; Zhang et al, 2016) \\
\hline TP53 & DDR, cell cycle & $\begin{array}{l}\text { Transcription factor inducing cell cycle arrest/ } \\
\text { senescence and apoptosis; induction of DNA repair } \\
\text { genes. }\end{array}$ & $\begin{array}{l}\text { (Muller et al, 2011; Muller \& Vousden, 2013; Kaiser \& } \\
\text { Attardi, 2017) }\end{array}$ \\
\hline$T P R$ & Nucleocytoplasmic transport & $\begin{array}{l}\text { Scaffolding element of the nuclear pore complex } \\
\text { essential for normal nucleocytoplasmic transport } \\
\text { of proteins and mRNAs. }\end{array}$ & (David-Watine, 2011) \\
\hline TRIOBP & Cytoskeleton regulation & $\begin{array}{l}\text { Might be involved in actin remodeling, directed cell } \\
\text { movement, and cell cycle regulation. }\end{array}$ & (Bao et al, 2015; Thutkawkorapin et al, 2016) \\
\hline $\begin{array}{l}\text { TRMT6, } \\
\text { TRMT61A }\end{array}$ & tRNA modification & $\begin{array}{l}\text { Catalyses the formation of N1-methyladenine at } \\
\text { position } 58 \text { in initiator methionyl-tRNA. }\end{array}$ & (Shi et al, 2015; Macari et al, 2016) \\
\hline
\end{tabular}

increased RNA/DNA hybrids at telomeres. The S9.6 monoclonal antibody, which recognizes RNA/DNA hybrids (Hu et al, 2006), was used to perform DNA-RNA immunoprecipitation (Fig S7). The immunoprecipitated nucleic acids contained telomeres, indicating the presence of RNA/DNA hybrid structures consistent with previous analyses (Arora et al, 2014; Sagie et al, 2017). The signal was abolished upon pretreatment with RNase $\mathrm{H}$, which destroys the RNA part in RNA/DNA duplexes, demonstrating the specificity of the assay. However, the amounts of RNA/DNA hybrids at telomeres and at Alu repeats did not change notably during transformation, indicating that increased hybrids at telomeres are not responsible for increased replicative stress that may be induced during transformation.
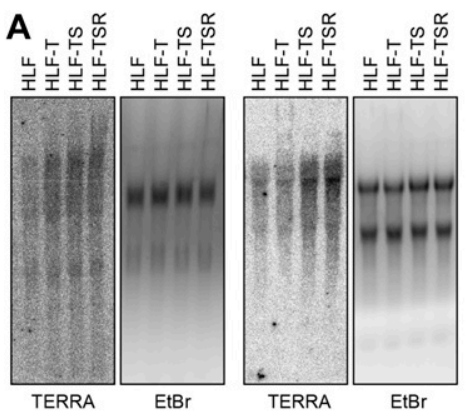

B

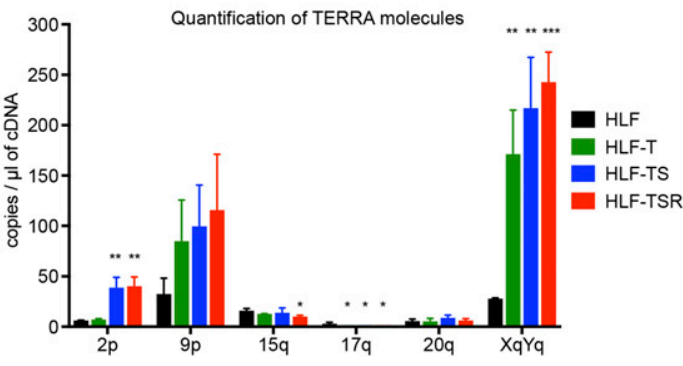

Figure 4. TERRA levels are elevated during transformation.

(A) Northern blot analysis of total RNA from the HLFderived cell lines. TERRA was detected using a telomeric DNA probe complementary to the UUAGGG repeats. Ethidium bromide (EtBr) staining is shown as a loading control. Two independent biological replicates are shown. (B) TERRA quantification by RT-qPCR with primers specific for the indicated subtelomeric sequences. Plotted is mean + SD from three biological and two technical replicates. Two-tailed unpaired $t$ test, comparing all derived cell lines with primary HLFs ( ${ }^{*} P<$ $0.05 ;{ }^{* *} P<0.01$; ${ }^{* * *} P<0.001$; bars lacking asterisks are not significant). 


\section{Up-regulated proteins prevent telomere fragility}

To test the hypothesis that during transformation, up-regulated proteins act against replicative stress at telomeres, we depleted candidate proteins (Fig 5A) using siRNA pools in HLF-TSR and HeLa cells. Measuring mRNA levels by RT-qPCR (Fig 5B) revealed efficient depletion of all candidates except for PNUTS, whose depletion strongly impacted on cell viability. Metaphase chromosomes were prepared and telomeric signals were detected by FISH. Replication stress at telomeres gives the so-called fragile telomeres, which are characterized by a smeary telomeric signal or multiple telomeric signals (Fig 5C). Telomere loss, apposition, and breakage ("outside") events were also scored (Table S2). Quantification revealed increases in telomere fragility upon depletion of several candidates. Depletion of NPAT scored only positively in HeLa cells. NPAT has known roles in transcriptional activation of histones but was not known to be also telomeric (Zhao et al, 2000). Its depletion caused accumulation of genomewide 53BP1 foci, a subset of which colocalized with telomeres (Fig S8). SAMHD1 plays, among others, roles in homology-directed repair (Daddacha et al, 2017). Its roles at telomeres are further characterized and discussed below. DCLRE1B/SNMB1/Apollo is a DNA 5'-3' exonuclease with roles in telomere end processing (Lenain et al, 2006; van Overbeek \& de Lange, 2006; Wu et al, 2012). Apollo also relieves topological stress during telomere replication (Ye et al, 2010). TMPO is a lamina-associated protein with roles in nuclear architecture and thus may contribute to telomere localization (Harris et al, 1995). PARP9 is a poly(ADP-ribose) polymerase involved in DNA repair (Yang et al, 2017). PNUTS binds and regulates protein phosphatase 1 , which among others is involved in the telomeric DDR, DNA repair, and DNA replication origin licensing (Kim et al, 2009; Landsverk et al, 2010; Hiraga et al, 2017).
PNUTS depletion caused accumulation of genome-wide 53BP1 foci, a subset of which colocalized with telomeres (Fig S8). SMCHD1 is required for $X$ chromosome inactivation (Nozawa et al, 2013). It preferentially associates with long telomeres (Grolimund et al, 2013) and has reported roles in DNA repair (Coker \& Brockdorff, 2014; Tang et al, 2014).

\section{SAMHD1 counteracts telomere breakage in TRF1-depleted cells}

SAMHD1 has been implicated in homology-directed repair of DNA double-strand breaks, recruiting CtIP to promote DNA end resection (Daddacha et al, 2017). In addition, SAMHD1 has been recently shown to stimulate processing of stalled replication forks (Coquel et al, 2018). To assess the roles of SAMHD1 in curbing replication stress or maintenance of telomere intactness, we depleted it in HeLa cells using shRNAs (Fig 6A). As a control, we induced local replication stress at telomeres by depleting TRF1. TRF1 prevents telomere fragility presumably through the recruitment of the BLM and RTEL1 helicases (Sfeir et al, 2009). SAMHD1 depletion enhanced telomere fragility slightly (Figs 5 and 6), whereas TRF1 depletion showed a stronger effect (Fig 6B and C, and Table S3). Strikingly, we observed that the co-depletion of SAMHD1 and TRF1 caused a novel telomere phenotype we referred to as "outsider" in which the telomere signal was detached from the telomeric chromatin of metaphase chromosomes (Fig 6B and D). No notable effects on telomere length could be observed in a TRF analysis in this shortterm experiment (Fig S9). Furthermore, the telomeres did not score positive for the presence of extrachromosomal DNA in the form of t-circles, which have been detected in cells that utilize the alternative lengthening of telomeres (ALT) mechanism (Cesare \& Griffith, 2004). The most straightforward interpretation of these results is
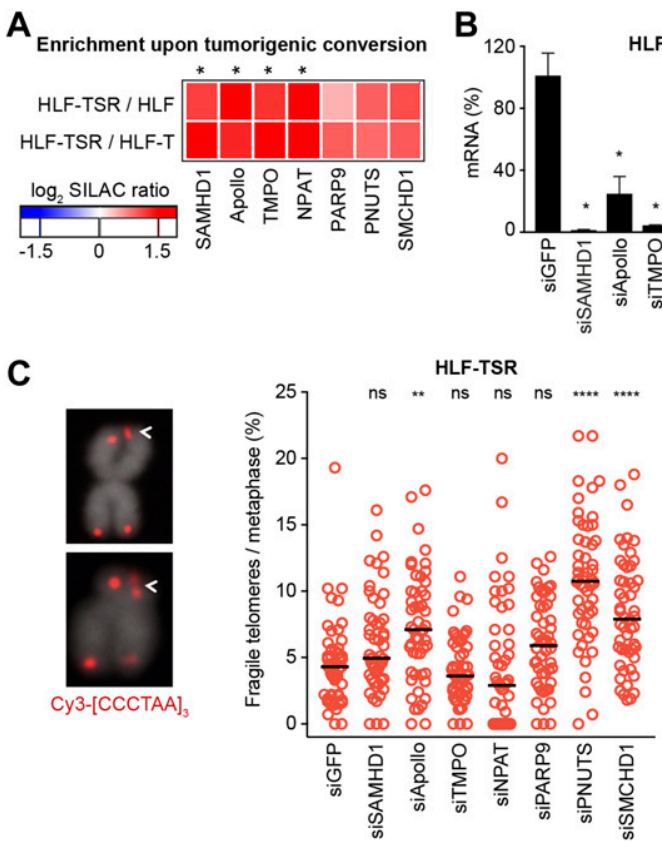

HLF-TSR
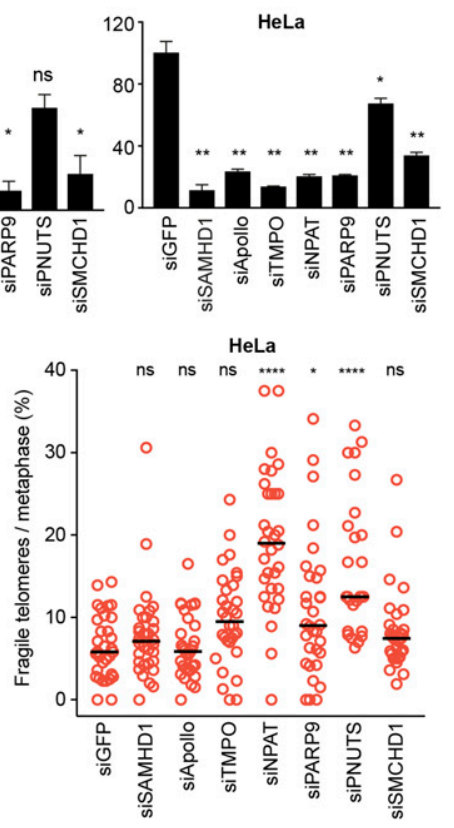

Figure 5. Cellular transformation up-regulates proteins that help preserve telomere integrity. siRNA screens were performed to test the effect of candidate depletion on telomere structure visualized on metaphase chromosome spreads. (A) Heatmap showing behavior of the selected candidates in QTIPS. Reported are mean SILAC ratios from the forward and reverse TRF IP replicates. The asterisks indicate proteins that were classified as significantly "transformation responsive" in the QTIP screen (Table S1, list C). (B) RT-qPCR to verify candidate depletion using siRNA pools in HLF-TSR and HeLa cells. Knockdown efficiency was compared with the mRNA levels in cells transfected with control siRNA against GFP. Plotted is mean + SD from two biological and two technical replicates for HLF-TSR and from two technical replicates from one representative experiment for HeLa. Two-tailed unpaired $t$ test $\left({ }^{\star} P<0.05\right.$; ${ }^{* \star} P<0.01$; ns $=$ not significant). (C) Analysis of fragile telomeres upon candidate depletion. Indicated telomere aberrations were scored on metaphase spreads with telomeres detected by FISH with a Cy3-[CCCTAA] $]_{3}$ probe (red) and DNA stained with DAPI (gray). HLF-TSR: $>50$ metaphases from two independent experiments (except for siGFP samples, for which data from three independent replicates) were analyzed for each condition. HeLa: $>25$ metaphases were analyzed per condition in a single experiment. The black line represents median. One-way ANOVA with Dunnett's multiple comparisons test, comparing all conditions to siGFP $\left({ }^{\star} P<0.05 ;{ }^{* \star} P<0.01\right.$; ${ }^{* * * *} P<0.0001 ; \mathrm{ns}=$ not significant). See also Table S2. 
A

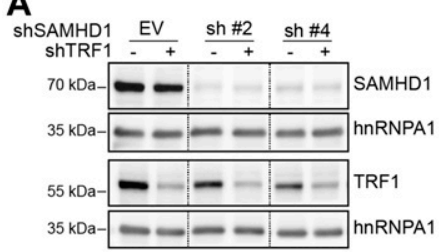

C

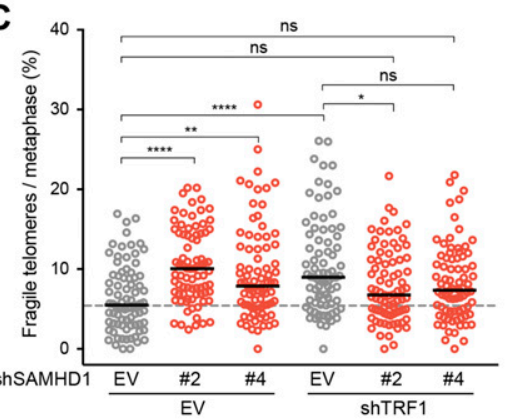

B

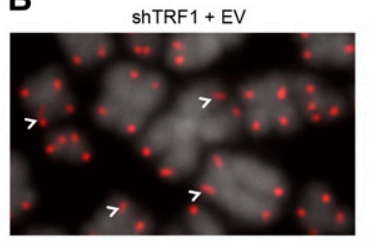

D

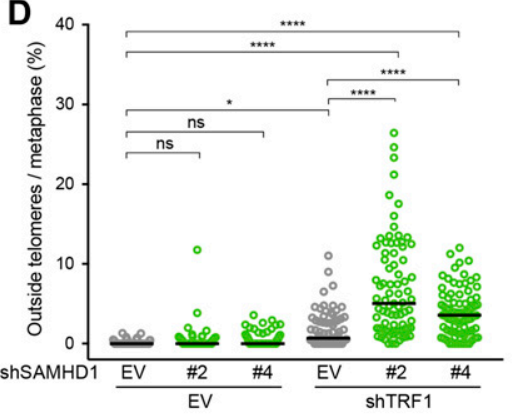

\section{E}

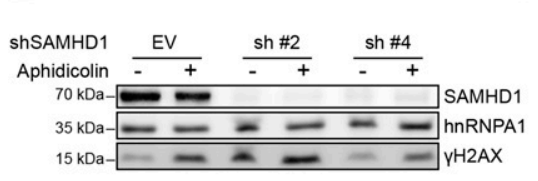

shTRF1 + shSAMHD1 \#2

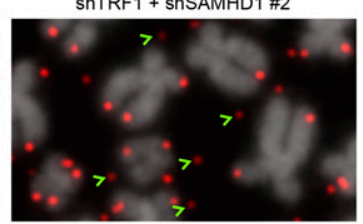

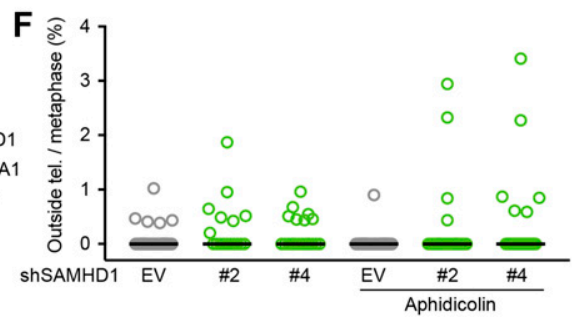

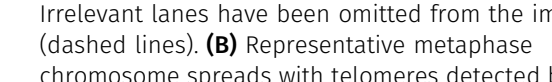
chromosome spreads with telomeres detected by FISH with a $\mathrm{Cy3}-[\mathrm{CCCTAA}]_{3}$ probe (red) and DNA stained with DAPI (gray). White arrows point to typical fragility (smears and multiple telomeric signals), whereas green arrows indicate outside telomeres (i.e., a telomeric signal positioned outside the DAPI signal). (C, D) Quantification of fragile and outside telomeres from cells in (A). 81 metaphases from three independent experiments were analyzed for each condition. The black line represents median. One-way ANOVA with Tukey's multiple comparisons test $\left({ }^{\star} P<0.05\right.$; ${ }^{* *} P<0.01$; ${ }^{* * * *} P<0.0001 ; \mathrm{ns}=$ not significant). (E, F) Effect of SAMHD1 depletion on telomere structure in aphidicolintreated HeLa cells. (E) Immunoblot verification of SAMHD1 depletion and DDR induction. Where indicated, the cells were treated with $0.1 \mu \mathrm{g} / \mathrm{ml}$ aphidicolin for $20 \mathrm{~h}$ before harvest. (F) Quantification of outside telomeric FISH signal on metaphase chromosome spreads from cells in (E). Shown are data from a representative experiment with $\geq 17$ metaphases and $>3,000$ telomeres analyzed per condition. Differences are not statistically significant. See also Table S3. that telomeres break in the absence of TRF1 during replication and that SAMHD1 is required for their repair.

We then tested if SAMHD1 depletion also triggers outsider telomeres in cells in which telomere fragility was induced by treatment with the DNA polymerase $\alpha$ and $\delta$ inhibitor aphidicolin (Figs 6E and F, and Table S3). However, the outsider phenotype was not triggered in this setting probably reflecting the different defects in TRF1-depleted versus DNA polymerase-inhibited cells.

\section{Discussion}

Changes in telomere length have been known for several decades to promote two key events during tumorigenesis, cellular senescence, and telomere crisis. Here, we discover that cellular transformation also involves crucial changes in telomere protein composition. We identify 134 proteins that are enriched in telomeric chromatin fractions of human fibroblasts. Importantly, 39 of these changed significantly in abundance at telomeres during oncogenic transformation. Many of the up-regulated proteins had been linked to cancer development in previous studies (Table 1); however, the link between their telomere recruitment and tumorigenesis remains unexplored. Most up-regulated telomeric factors play roles in either DNA replication, DNA repair, or telomere protection. The pre-replication complex (pre-RC) components ORC1, 3, and 5 and MCM4, 6, and 7 may be recruited to telomeres via TRF2, which becomes more abundant during transformation. It remains to be tested if the recruited pre-RC components form active origins. Origin firing within telomeres occurs rarely, but dormant origins within telomeres may be activated upon stalling of replication forks that enter the telomeres from subtelomeric regions (Drosopoulos et al, 2015). We also identify Apollo/DCLRE1B as a transformation up-regulated factor, which has been reported to counteract topological stress at telomeres (Ye et al, 2010). In support of a role in curbing replication stress, Apollo/DCLRE1B depletion increased telomere fragility. In addition, we identify six novel factors that were upregulated during transformation and whose depletion caused telomere fragility.

Oncogene-induced hyperproliferation leads to replication stress, possibly involving depletion of nucleotides or increased collisions with transcription complexes, although the exact mechanism remains unknown (Bartek et al, 2007; Hills \& Diffley, 2014). During transformation of HLFs, TERRA levels but not DNA/RNA hybrids increased. Thus, increased telomere transcription may contribute to telomere fragility, although other mechanisms should not be excluded. We propose that the up-regulation of factors that suppress telomere fragility is critical to resist oncogene-induced replication stress at telomeres during transformation. The fragility-suppressing factors were induced upon expression of SV40 T antigens inactivating p53, RB, and protein phosphatase 2A. Expression of oncogenic H-RasV12, which was introduced as a last step in our transformation protocol, did not contribute to their up-regulation. During natural carcinogenesis, oncogene-induced hyperproliferation precedes inactivation of p53 and RB and therefore oncogene-induced senescence may be promoted (Halazonetis, 2004; Gorgoulis et al, 2005; Bartkova et al, 2006; Di Micco et al, 2006; Halazonetis et al, 2008; Suram et al, 2012). Our results suggest that targeting of p53, RB, and PP2A by SV40 T antigens 
not only alleviates checkpoint-induced cell cycle control but also triggers expression of factors that suppress DNA damage upon replication stress, which is prevalent at telomeres (Fig 7A).

One of the top candidates up-regulated upon transformation of HLFs was SAMHD1. Therefore, we decided to explore its functions at telomeres. SAMHD1 is a dNTPase, which restricts HIV-1 replication (Laguette et al, 2011). SAMHD1 is mutated in cancer (Clifford et al, 2014; Merati et al, 2015; Rentoft et al, 2016) and in the neurodegenerative autoimmune disorder Aicardi-Goutières syndrome in which aberrant nucleic acids accumulate, inducing innate immunity (Ballana \& Este, 2015). More recently, SAMHD1 functions in homology-directed DNA repair (Daddacha et al, 2017) and DNA replication (Coquel et al, 2018) have been discovered. Specifically, SAMHD1 recruits CtIP to DNA double-strand breaks to facilitate end resection and homologous recombination (HR) (Daddacha et al, 2017). We find that double depletion of TRF1 and SAMHD1 gives outsider telomeres, which seem broken off from the chromosome arms. We suspect that this phenotype can be ascribed to the functions of SAMHD1 in $\mathrm{HR}$ and we propose the following model (Fig 7B). TRF1 depletion gives telomere fragility because of inefficient recruitment of the G-quadruplex unwinding helicases BLM and RTEL1. Therefore, replication forks may stall and are eventually processed into DNA double-strand breaks near the telomere-subtelomere boundary. In SAMHD1-proficient cells, the breaks are repaired by homology-directed repair. In SAMHD1-deficient cells, the broken forks remain unrepaired. However, the telomeric FISH signals of outsider telomeres indicate that telomere replication does proceed downstream of the break, possibly triggered by repriming events or activation of telomeric origins that converge toward the double-strand break (Pasero \& Vindigni, 2017). A contribution of telomerase in promoting telomere synthesis downstream of the broken fork cannot be excluded. The latter was seen in fission yeast in which the TRF1-ortholog Taz1 was deleted (Miller et al, 2006). Loss of Taz1 led to

\section{A}

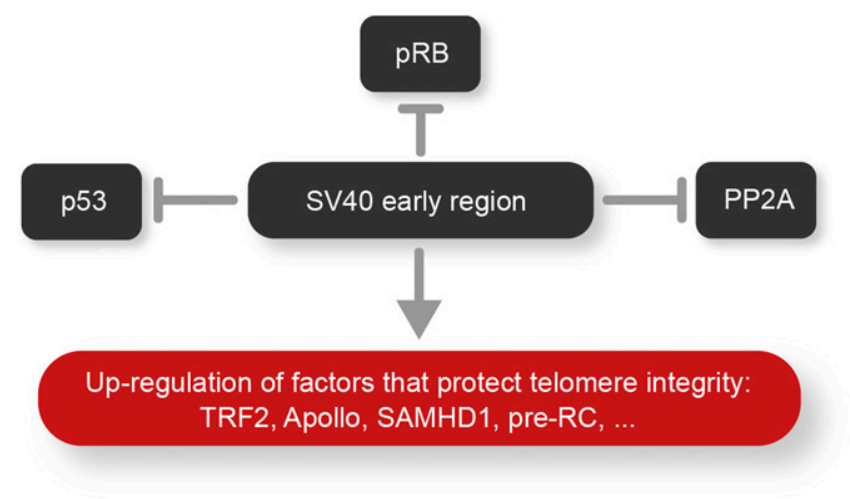

B

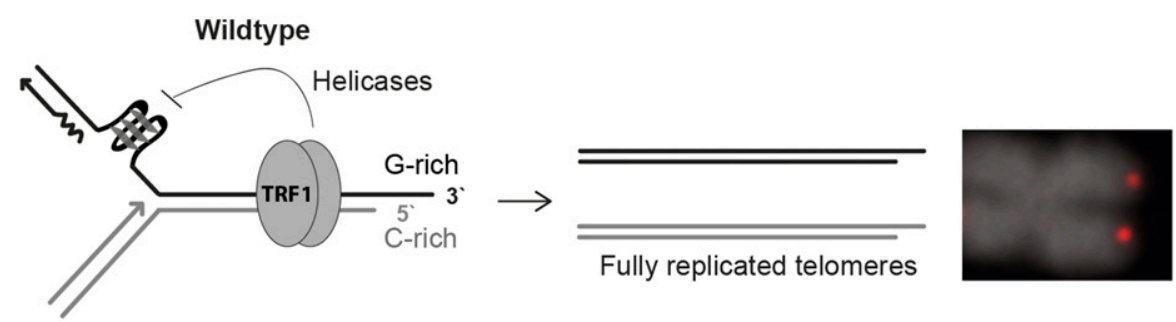

TRF1 deficiency

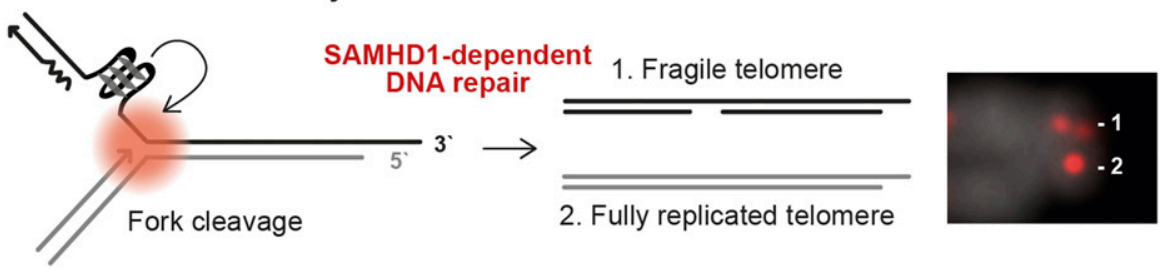

TRF1 and SAMHD1 deficiency
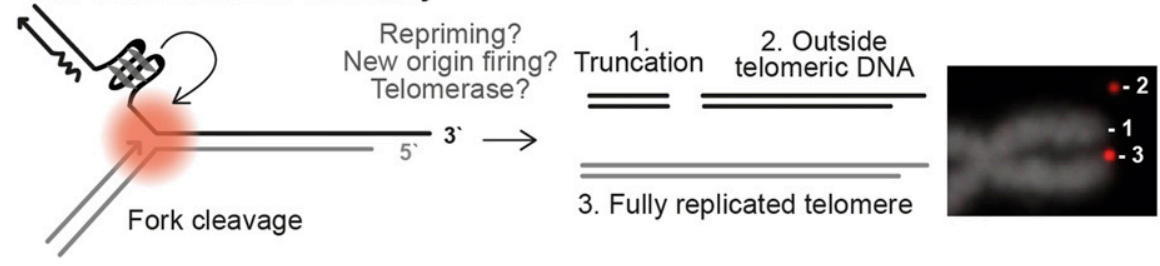

Figure 7. Hypothetical model for transformationassociated changes at telomeres.

(A) The SV40 large T and small t antigens inhibit p53, RB, and PP2A. In addition, SV40 early gene expression leads to up-regulation of factors, which promote telomere protection and replication. (B) Telomere replication requires TRF1. In the absence of TRF1, G-quadruplex structures accumulate at telomeres, which become cleaved during replication and repaired by SAMHD1dependent repair. In the absence of both TRF1 and SAMHD1, double-strand breaks are retained. Telomere synthesis proceeds downstream of the breaks mediated by replication fork restart, telomerase, or replication fork firing from within telomeric repeats. 
stalled replication forks at telomeres, which could be maintained only in the presence of telomerase.

Overall, our study underlines the importance of telomere replication stress in cellular transformation. It identifies a number of novel factors that are induced by SV40 T antigens to counteract telomere fragility. Deregulation of these proteins at telomeres might play an unrecognized role in the development of cancer, as exemplified by SAMHD1, which has been found mutated in cancer cells and seems to have a pivotal function in the preservation of telomere integrity. This work will stimulate further studies to unravel the mechanisms that underlie telomere replication stress and oncogene-induced senescence during transformation.

\section{Materials and Methods}

\section{Cell lines}

The following cell lines were used: HeLa; HEK293T; HLF (Ducrest et al, 2001); HLF-T-HLF cells stably infected with hTERT expressing retroviruses; HLF-TS-HLF-T cells stably infected with SV40 early region expressing retroviruses; HLF-TSR-HLF-TS cells stably infected with H-RasV12 expressing retroviruses; HCT116; and HCT116 ${ }^{\text {DKO }}$-HCT116 cells with genetic disruption of DNMT1 and DNMT3b (Rhee et al, 2002). Cells were maintained in DMEM (Gibco) containing 10\% FBS (Gibco), $100 \mathrm{U} / \mathrm{ml}$ penicillin, and $100 \mu \mathrm{g} / \mathrm{ml}$ streptomycin at $37^{\circ} \mathrm{C}$ in a humidified incubator containing $5 \% \mathrm{CO}_{2}$. Conditions for SILAC labeling were reported previously (Grolimund et al, 2013; Majerska et al, 2017).

\section{Plasmids}

Recombinant retroviruses were produced in HEK293T cells transfected with a pBABE expression vector (pBABE-hygro-hTERT [Cristofari \& Lingner, 2006], pBABE-puro-HRasV12 [9051; Addgene], pBABE-neo-largeTgenomic [10891; Addgene]), and pcl-Ampho packaging vector (Naviaux et al, 1996). For validation of telomeric localization of candidate proteins by anti-HA ChIP, cDNAs from HLF-TSR cells were amplified by PCR and introduced by InFusion cloning (Clontech) into pcDNA6-derived vectors (Invitrogen) for expression as 3xHA-tagged proteins. The shRNAexpressing vectors were generated by cloning the corresponding double-stranded DNA oligonucleotides into psuper vectors digested with Bglll and HindIII. The targeting sequences are as follows: pSuper-blast-shSAMHD1 \#2 5'-CGCATGCTGAAGCTAAGTA-3'; pSuper-blast-shSAMHD1 \#4 5'-GTATCGCATTTCTACAGCA-3'; and pSuper-puro-shTRF1 5'-GAATATTTGGTGATCCAAA-3'.

\section{QTIP}

QTIP experiments were carried out as described previously (Grolimund et al, 2013; Majerska et al, 2017) with the following modifications. $240-490 \times 10^{6}$ cells of each cell type were used per IP. Upon mixing the two cell types in a 1:1 ratio, cells in suspension were cross-linked for $10 \mathrm{~min}$ at $25^{\circ} \mathrm{C}$ using a combination of $1 \%$ formaldehyde and $2 \mathrm{mM}$ ethylene glycol bis(succinimidyl succinate). Chromatin-enriched pellets were resuspended at $25 \times 10^{6}$ cells $/ \mathrm{ml}$ in LB3 buffer (10 mM Tris-HCl, pH 8.0; $200 \mathrm{mM} \mathrm{NaCl} 11 \mathrm{mM}$ EDTA$\mathrm{NaOH}, \mathrm{pH} 8.0 ; 0.5 \mathrm{mM}$ EGTA-NaOH, pH 8.0; 0.1\% w/v sodium deoxycholate; $0.25 \% \mathrm{w} / \mathrm{v}$ sodium lauryl sarcosinate; and EDTA-free protease inhibitor complex [Roche]) and sonicated for $12 \mathrm{~min}$ at $4^{\circ} \mathrm{C}$ using the Focused-ultrasonicator (Covaris E220; $12 \times 12-\mathrm{mm}$ glass tubes with AFA fiber; duty: 5.0, peak incident power: 140, cycles: 200, amplitude: 0, velocity: 0, and dwell: 0). Immunoprecipitation was performed using beads covalently coupled with nonspecific IgGs (sc-2027; Santa Cruz Biotechnology) or beads coupled to affinity-purified anti-TRF1 (rabbit \#714) and antiTRF2 antibodies (rabbit \#40) according to the previously published protocol (Aeby et al, 2016).

\section{Mass spectrometry analysis and data processing}

LC-MS/MS analysis was performed as described previously (Aeby et al, 2016). Raw MS data were analyzed using MaxQuant software (Cox \& Mann, 2008) with FDR $<0.01$ at the level of both proteins and peptides. Peak lists were searched against the human Uniprot database, using Arg10 and Lys8 as heavy labels (multiplicity of 2). The mass tolerance was set to $7 \mathrm{ppm}$ for precursor ions and MS/MS accuracy was set at 0.5 D. Enzyme was set to trypsin with up to two missed cleavages. Proteins and peptides (minimum six amino acids) were identified using a target-decoy approach with a reversed database. At least two (unique + razor) peptides were required for protein identification. A cutoff was set to 0.1 for posterior error probability.

TRF/IgG enrichment was determined using MS/MS spectral counts, which were calculated from the evidences of protein groups. For each protein group, we summed up the MS/MS counts for each experiment. At least three MS/MS spectral counts were required per condition. The missing values were imputed with pseudo-counts of 0.5 . The normalization of the spectral counts was performed following the normalization schema in Scaffold (http:/ / www.proteomesoftware.com/products/scaffold/). Further statistical analyses and graphical displays were performed in Perseus software version 1.5.3.2 (http://www.coxdocs.org/), using mean values of the forward and reverse QTIP replicates. The expression values and ratios were $\log _{2}$-transformed and normalized by subtracting the median. Proteins enriched in TRF IP over control IgG IP (i.e., showing significant TRF/IgG ratios) were calculated separately for each QTIP as statistically significant outliers using a Significance A left-sided test $(P<0.05)$. Only proteins with significant TRF/IgG ratio in at least two of four QTIPS were considered "telomeric." Upon manual inspection, proteins HRG and SERPINC1 were removed from the list of telomeric proteins because they were light labeled in both label-swap experiments, indicating they were external contaminants. Significant SILAC ratios were determined for each QTIP (both, for inputs and TRF IPS) using a Significance B two-sided test (both sides, $P<0.05$ ). Proteins with a significant SILAC ratio in at least one of the four QTIPS were considered "transformation responsive." To create heatmaps, hierarchical clustering was performed in Perseus based on average Euclidean distance of the $\log _{2}$ mean SILAC ratios. The mass spectrometry proteomics data have been deposited to the ProteomeXchange Consortium via the PRIDE (Vizcaino et al, 2016) partner repository with the dataset identifier PXD010088. 


\section{siRNA and plasmid transfection}

The cells were transfected with siRNA pools ( 5 pmol of each siRNA per well of a six-well plate) by calcium phosphate precipitation twice with a 36-h interval and harvested 80-100 h after the first transfection. siRNA oligonucleotides were purchased from Qiagen: SAMHD1 (SI00710500, SI04137217, SI04189332, and SI04243673), DCLRE1B (SI00134757, SI02778692, and SI02778699), TMPO (SI03215730, SI04951156, and SI04951163), NPAT (SI00660814, SI04343157, and SI04355708), PARP9 (SI04136244, SI04196108, SI04212642, and SI04247285), PNUTS (SI00041811, SI00041832, SI03032666, and SI03088141), and SMCHD1 (SI00454664 and SI00454678). SiGFP 5'-GCAGCACGACTTCTTCAAGTT-3' was synthesized at Microsynth. For transient overexpression of 3xHA-tagged proteins, HEK293T cells in a 15-cm tissue culture dish were transfected with $30 \mu \mathrm{g}$ of plasmid DNA using calcium phosphate precipitation. Cells were harvested for ChIP analysis 42-48 h post-transfection. HeLa cells were transfected with pSuper-Puro and pSuper-Blast constructs using Lipofectamine 2000 (Invitrogen) according to the manufacturer's protocol. $1 \mu \mathrm{g} / \mathrm{ml}$ puromycin and $5 \mu \mathrm{g} / \mathrm{ml}$ blasticidin were added to the medium $1 \mathrm{~d}$ after the transfection, and selection was maintained for $5 \mathrm{~d}$.

\section{Chromatin immunoprecipitation}

HEK293T cells were cross-linked with 1\% formaldehyde for 25 min, resuspended in LB3 buffer $\left(20-30 \times 10^{6}\right.$ cells $\left./ \mathrm{ml}\right)$, and sonicated for 30 min at $4^{\circ} \mathrm{C}$ using a Focused-ultrasonicator as described in the QTIP protocol. The sonicated extracts were centrifuged at $4^{\circ} \mathrm{C}$ for $15 \mathrm{~min}$ at 20,000 $\mathrm{g}$ and the supernatant was mixed with four volumes of ChIP dilution buffer and precleared for $1 \mathrm{~h}$ at $4^{\circ} \mathrm{C}$ with Sepharose 6B (Sigma-Aldrich) pre-blocked with yeast tRNA $(0.5 \mathrm{mg} / \mathrm{ml}$ of beads). The precleared lysate corresponding to $2 \times 10^{6}$ cells was supplemented with $40 \mu$ l of yeast tRNA-blocked Protein G 50\% bead slurry (GE Healthcare Life Sciences) and $3 \mu \mathrm{g}$ of anti-HA antibody (ab9110; Abcam). After an overnight incubation at $4^{\circ} \mathrm{C}$, the beads were washed as for QTIP. The DNA from input and IP samples was isolated and analyzed by dot blot hybridization as described previously (Grolimund et al, 2013).

\section{Northern blotting analysis of TERRA}

RNA extraction was performed using RNeasy Mini kit (Qiagen) according to manufacturer's protocol. Northern blot TERRA analysis was performed as described previously (Azzalin et al, 2007). In brief, $10 \mu \mathrm{g}$ of total RNA was separated by electrophoresis in a $1.2 \%$ formaldehyde agarose gel and blotted onto a nylon membrane (Hybond $\mathrm{N}+$; GE Healthcare Life Sciences). Upon UV-cross-linking, the membrane was hybridized overnight with a $\left[\alpha^{32} \mathrm{P}\right]$-dCTPlabeled telomeric probe at $50^{\circ} \mathrm{C}$. After hybridization, the membrane was washed three times with a $1 \times$ SSC/0.5\% SDS solution for 20 min at $60^{\circ} \mathrm{C}$. Radioactive signals were detected using a phosphorimager (FLA-3000; Fujifilm).

\section{Standard curves for TERRA copy number determination}

To determine the copy number of TERRA in the qPCR reactions, we constructed a standard curve for each TERRA based on a recombinant plasmid containing the desired subtelomere sequence. The subtelomeres were amplified from HeLa genomic DNA using Phusion Green High-Fidelity DNA polymerase and the primers listed in Table S4. The PCR products were isolated from the gel, purified using the Qiagen gel extraction kit, and cloned in the PCR4 BLUNT-TOPO vector using the Zero Blunt TOPO PCR cloning kit for sequencing. All the plasmids were sequenced to confirm the subtelomere sequence. To construct the standard curves for each TERRA, we made a 10fold serial dilution of each plasmid ranging from $3 \times 10^{8}$ to $3 \times$ $10^{-1}$. The concentration of each plasmid was determined using Qubit 4 Fluorometer (Invitrogen). We calculated the copy number concentration using the following formula:

$$
\text { DNA (copy) }=\frac{6.02 \times 10^{23}\left(\text { copies } \mathrm{mol}^{-1}\right) \times \text { DNA amount }(\mathrm{g})}{\text { DNA length }(\mathrm{bp}) \times 660\left(\mathrm{~g} \mathrm{~mol}^{-1} \mathrm{bp}^{-1}\right)} \text {. }
$$

Each standard curve was performed in duplicate. The $C_{T}$ values were plotted against the logarithm of the plasmid copy number and the standard curve was generated by a linear regression of the points. The PCR amplification efficiency was calculated as a percentage from the slope of the curve using the following formula:

$$
E=\left(10^{\frac{-1}{\text { slope }}}-1\right) \times 100
$$

\section{RT-qPCR analysis of TERRA}

RNA was isolated using RNeasy Mini kit (Qiagen) according to the manufacturer's protocol. The RNA was reversed-transcribed using the Invitrogen Superscript III Reverse Transcriptase as previously described (Feretzaki \& Lingner, 2017). The cDNA was diluted $1 / 2$ for routine relative quantification $q P C R$ or $1 / 2$ and $1 / 5$ for absolute quantification. qPCR runs included both a no-template control and a no-reverse transcription control. All the experiments were performed in three biological replicates. qPCR was performed as previously described (Feretzaki \& Lingner, 2017). To determine and analyze the relative changes in TERRA expression between the samples, we applied the $2^{-\triangle \Delta C t}$ method. The number of TERRA copies in the $q P C R$ or the cDNA template was calculated based on the standard curve.

\section{RT-qPCR analysis of depletion efficiency}

$3 \mu \mathrm{g}$ of RNA was reverse-transcribed using SuperScript III RT (Invitrogen) with $150 \mathrm{ng}$ random primers (Promega) and $500 \mathrm{ng}$ oligo (dT) 15 primers (Promega). The qPCR was performed as previously described (Feretzaki \& Lingner, 2017) using primers listed in Table S5.

\section{Telomeric FISH on metaphase chromosomes}

Cells were treated with $0.05 \mu \mathrm{g} / \mathrm{ml}$ demecolcine for $2 \mathrm{~h}$, harvested, and incubated in $0.056 \mathrm{M} \mathrm{KCl}$ at $37^{\circ} \mathrm{C}$ for $7 \mathrm{~min}$. Swollen cells were 
fixed in cold methanol/acetic acid (3:1) overnight and spread on glass slides. After ageing overnight, the slides were rehydrated in $1 \times$ PBS, fixed in $4 \%$ formaldehyde, and dehydrated in an ethanol series. The slides were allowed to air-dry before applying the hybridization solution ( $10 \mathrm{mM}$ Tris- $\mathrm{HCl}, \mathrm{pH} 7.4 ; 70 \%$ formamide; and $0.5 \%$ blocking reagent [Roche]) containing Cy3-OO-(CCCTAA) ${ }_{3}$ PNA probe. The spreads were denatured at $80^{\circ} \mathrm{C}$ for 3 min and hybridized at RT for $3 \mathrm{~h}$. The slides were washed twice for $15 \mathrm{~min}$ with $10 \mathrm{mM}$ Tris- $\mathrm{HCl}(\mathrm{pH} 7.4) / 70 \%$ formamide, and three times for $5 \mathrm{~min}$ with $0.1 \mathrm{M}$ Tris- $\mathrm{HCl}(\mathrm{pH} 7.4) / 0.15 \mathrm{M} \mathrm{NaCl} / 0.08 \%$ Tween-20 with DAPI in the second wash. The slides were dehydrated in an ethanol series and mounted in Vectashield embedding medium. Images were acquired using a Zeiss Axioplan II microscope.

\section{Immunofluorescence FISH}

Cells were grown on coverslips, fixed in $4 \%$ formaldehyde, and permeabilized for 5 min in $0.1 \%$ Triton X-100/0.02\% SDS/1× PBS, and then pre-blocked for $10 \mathrm{~min}$ in $2 \% \mathrm{BSA} / 1 \times \mathrm{PBS}$ and blocked for $45 \mathrm{~min}$ in $10 \%$ goat serum $/ 2 \%$ BSA $/ 1 \times$ PBS. Cells were then incubated with $0.5 \mu \mathrm{g} / \mathrm{ml} \alpha$-53BP1 antibody (NB100-304; Novus Biologicals) for $1 \mathrm{~h}$, washed three times for 4 min in $2 \%$ BSA/1× PBS, and incubated with Alexa Fluor 633-conjugated secondary antibody (1:500, A-21070; Invitrogen) for 30 min. After three washes in PBS, stained cells were fixed in $4 \%$ formaldehyde for 5 min. Both antibodies were diluted in $10 \%$ goat serum $/ 2 \%$ BSA $/ 1 \times$ PBS, and all steps of the IF protocol were performed at RT. For telomeric FISH, the stained and fixed coverslips were dehydrated in an ethanol series, air-dried, and hybridized with the Cy3-OO-(CCCTAA) ${ }_{3}$ PNA probe as described above. Images were captured using a Zeiss LSM 700 confocal microscope.

\section{Telomere Restriction Fragment (TRF) analysis}

Genomic DNA was isolated using the Wizard Genomic DNA Purification kit (Promega) and subjected to restriction digestion with Rsal and Hinfl, in the presence of RNase A, at $37^{\circ} \mathrm{C}$ overnight. Digested DNA was extracted using phenol-chloroform-isoamyl alcohol, followed by isopropanol precipitation. $1 \mu \mathrm{g}$ of digested DNA was separated on $1 \%$ agarose gel by pulsed-field gel electrophoresis using a Bio-Rad CHEF DR-II apparatus or on $0.8 \%$ agarose gel by constant field gel electrophoresis. The gels were dried and hybridized with $\left[\alpha^{32} \mathrm{P}\right]-\mathrm{dCTP}-$ labeled telomeric probe at $50^{\circ} \mathrm{C}$ as described (Grolimund et al, 2013). Radioactive signals corresponding to single-stranded telomeric DNA were detected using a phosphorimager (FLA-3000; Fujifilm). Thereafter, the gel was denatured in $0.5 \mathrm{M} \mathrm{NaOH}, 1.5 \mathrm{M} \mathrm{NaCl}$ for $30 \mathrm{~min}$, neutralized for $15 \mathrm{~min}$ with $0.5 \mathrm{M}$ Tris $-\mathrm{HCl}, \mathrm{pH} 7.5$, and $1.5 \mathrm{M} \mathrm{NaCl}$; and hybridized again to detect total telomeric DNA.

\section{Immunoblot analysis}

Immunoblots were incubated separately with the following primary antibodies: anti-ATM pS1981 (1:1,000, ab81292; Abcam), anti-Chk2 pT68 (1:1,000, 2661; Cell Signaling), anti-p53 (1:1,000, sc-126; Santa Cruz), anti-p21 (1:5,000, ab109520; Abcam), anti-Actin (1:2,000, sc1616; Santa Cruz), anti-TRF2 (1:1,000, 05-521; Millipore), and anti- $\gamma \operatorname{H2AX}(1: 1,000,05-636 ;$ Millipore), followed by a corresponding horseradish peroxidase-conjugated secondary antibody.

\section{Flow cytometry analysis}

Following fixation in $70 \%$ ethanol, the pellet from $5 \times 10^{5}$ cells was resuspended in $250 \mu \mathrm{l}$ of PBS containing $0.2 \mu \mathrm{g} / \mathrm{ml}$ RNAse A and incubated for $15 \mathrm{~min}$ at $37^{\circ} \mathrm{C}$. The DNA was stained by adding $250 \mu \mathrm{l}$ of $80 \mu \mathrm{g} / \mathrm{ml}$ of propidium iodide, followed by 10 -min incubation at $4^{\circ} \mathrm{C}$ in the dark. $250 \mu \mathrm{l}$ of PBS was added to each sample before FACS analysis on Accuri C6 (BD Biosciences). The percentage of cells in each phase of the cell cycle was determined using the Watson Pragmatic computational model in FlowJo software (TreeStar).

\section{DNA/RNA hybrid immunoprecipitation}

$60-80 \times 10^{6}$ cells were harvested for each condition and lysed for 5 min in cold RLN buffer ( $50 \mathrm{mM}$ Tris-Cl, pH 8.0; $140 \mathrm{mM} \mathrm{NaCl} ; 1.5 \mathrm{mM}$ $\mathrm{MgCl}_{2} ; 0.5 \% \mathrm{v} / \mathrm{v}$ Nonidet P-40; $175 \mu \mathrm{l}$ buffer per $10 \times 10^{6}$ cells) supplemented with $1 \mathrm{mM}$ DTT and $100 \mathrm{U} / \mathrm{ml}$ RNasin Plus (Promega). After centrifugation $\left(300 \mathrm{~g}, 2 \mathrm{~min}, 4^{\circ} \mathrm{C}\right.$ ), the nuclei-enriched pellet was resuspended in RLT buffer (RNeasy Plus kit; [Qiagen]; $500 \mu \mathrm{l}$ buffer per $20 \times 10^{6}$ cell equivalent) supplemented with $\beta$ mercaptoethanol at $10 \mu \mathrm{l} / \mathrm{ml}$ and homogenized by passing through an insulin needle. Nucleic acids were thereafter isolated by a phenol:chloroform:isoamylalcohol (25:24:1; Biosolve BV) separation, followed by isopropanol precipitation. The nucleic acids were dissolved in $\mathrm{H}_{2} \mathrm{O}\left(400 \mu \mathrm{l}\right.$ per $20 \times 10^{6}$ cell equivalent) and sonicated using a Focused-ultrasonicator (Covaris E220) to obtain DNA fragments below $500 \mathrm{bp}$. $150 \mu \mathrm{l}$ of sonicated nucleic acids were treated for $90 \mathrm{~min}$ at $37^{\circ} \mathrm{C}$ with either $10 \mu \mathrm{l}$ of RNase $\mathrm{H}(1 \mathrm{U} / \mu \mathrm{l}$; Roche) or $\mathrm{H}_{2} \mathrm{O}$. The reaction was stopped by addition of $2 \mu \mathrm{l}$ of $0.5 \mathrm{M}$ EDTA. The samples were mixed with $1,738 \mu \mathrm{l}$ of buffer $1(10 \mathrm{mM}$ Hepes-KOH, pH 7.5; 275 mM NaCl; 0.1\% SDS; 1\% Triton X-100; and 0.1\% $\mathrm{Na}$-deoxycholate) and precleared for $1 \mathrm{~h}$ at $4^{\circ} \mathrm{C}$ with $80 \mu \mathrm{l}$ of $50 \%$ Protein $\mathrm{G}$ bead slurry (GE Healthcare Life Sciences) that had been pre-blocked for $1 \mathrm{~h}$ at $4^{\circ} \mathrm{C}$ with yeast tRNA ( $1 \mathrm{mg}$ tRNA per $1 \mathrm{ml}$ of $50 \%$ bead slurry). The IP reactions were set up containing $800 \mu \mathrm{l}$ of precleared extract, $40 \mu \mathrm{l}$ of tRNA-blocked Protein G beads, and $1 \mu \mathrm{g}$ of S9.6 antibody (022715; Kerafast) or mouse IgG (sc-2025; Santa Cruz Biotechnology). The reactions were incubated for $90 \mathrm{~min}$ at $4^{\circ} \mathrm{C}$ on a rotating wheel and then washed consecutively for 5 min each time with $1 \mathrm{ml}$ of buffer 2 (50 mM Hepes- $\mathrm{KOH}, \mathrm{pH} 7.5 ; 140 \mathrm{mM} \mathrm{NaCl}$; 1\% Triton X-100; 0.1\% Na-deoxycholate; and $1 \mathrm{mM}$ EDTA), buffer 3 (50 mM Hepes- $\mathrm{KOH}, \mathrm{pH}$ 7.5; 500 mM NaCl; 1\% Triton X-100; 0.1\% Nadeoxycholate; and $1 \mathrm{mM}$ EDTA), buffer 4 (10 mM Tris- $\mathrm{HCl}$, pH 8.0; 250 mM LiCl; 1\% NP-40; 1\% Na-deoxycholate; and 1 mM EDTA), and 1× TE buffer (10 mM Tris- $\mathrm{HCl}, \mathrm{pH}$ 8.0, and $1 \mathrm{mM}$ EDTA). The input and precipitated DNA was analyzed by dot blot hybridization.

\section{T-circle assay}

T-circle assay was modified from the work of Zellinger et al (2007). $2 \mu \mathrm{g}$ of genomic DNA was digested with $10 \mathrm{U} / \mu \mathrm{g}$ (each) Hinfl and $\mathrm{Mbol}$ (New England Biolabs) in CutSmart buffer in the presence of $10 \mu \mathrm{g} / \mathrm{ml}$ RNase A overnight at $37^{\circ} \mathrm{C} .1 .5 \mu \mathrm{g}$ of cut DNA was ethanolprecipitated and resuspended in an annealing buffer ( $0.2 \mathrm{M}$ Tris, $\mathrm{pH}$ 
7.5; $0.2 \mathrm{M} \mathrm{KCl}$; and $1 \mathrm{mM}$ EDTA) with $1 \mu \mathrm{M}(\mathrm{CCCTAA})_{3}$ primer containing thiophosphate linkages between the three $3^{\prime}$ terminal nucleotides. The mix was denatured at $96^{\circ} \mathrm{C}$ for 5 min and cooled down to $25^{\circ} \mathrm{C}$ for $2 \mathrm{~h}$. DNA was ethanol-precipitated and resuspended in $10 \mu \mathrm{l}$ of $\mathrm{H}_{2} \mathrm{O}$ for the T-circle reaction ( $10 \mu \mathrm{l}$ sample combined with $10 \mu \mathrm{l} 0.2$ $\mathrm{mg} / \mathrm{ml} \mathrm{BSA}, 0.1 \%$ Tween, $1 \mathrm{mM}$ each dATP, dGTP, dTTP, dCTP, $1 \times$ \$29 buffer, and $7.5 \mathrm{U} \phi 29$ DNA polymerase [New England Biolabs]). Primer extension was carried out at $30^{\circ} \mathrm{C}$ for $12 \mathrm{~h}$. The $\phi 29$ DNA polymerase was inactivated by incubation at $65^{\circ} \mathrm{C}$ for $20 \mathrm{~min}$. The extension products were separated by agarose gel electrophoresis ( $0.6 \%$ agarose at $2 \mathrm{~V} / \mathrm{cm}$ for $16 \mathrm{~h}$ ). The gel was then dried at $50^{\circ} \mathrm{C}$ for $2 \mathrm{~h}$, denatured and hybridized with a specific telomeric probe. U2OS genomic DNA of the ALT cell line was used as a positive control.

\section{Supplementary Information}

Supplementary Information is available at https://doi.org/10.26508/lsa. 201800121

\section{Acknowledgements}

We thank Patricia Renck Nunes for providing the plasmids for TERRA copy number determination. We gratefully acknowledge Patrick Reichenbach for immortalization of HLFs. The mass spectrometry analysis was performed by the Proteomics Core Facility and Technology Platform at Ecole Polytechnique Fédérale de Lausanne (EPFL) (Florence Armand, Romain Hamelin, and Marc Moniatte). Members of the Lingner laboratory are thanked for discussions, technical advice, and sharing reagents. Research in I Lingner's laboratory was supported by the Swiss National Science Foundation (SNSF), the SNSFfunded NCCR RNA and disease network, an Initial Training Network grant (CodeAge) from the European Commission's Seventh Framework Programme (grant agreement no. 316354), the Swiss Cancer League, and EPFL. M Feretzaki was supported by a Marie Curie postdoctoral fellowship.

\section{Author Contributions}

J Lingner: conceptualization, funding acquisition, and writing-original draft, review, and editing.

J Majerska: data curation, investigation, methodology, project administration, and writing-review and editing.

M Feretzaki: investigation.

G Glousker: investigation.

\section{Conflict of Interest Statement}

The authors declare that they have no conflict of interest.

\section{References}

Aeby E, Ahmed W, Redon S, Simanis V, Lingner J (2016) Peroxiredoxin 1 protects telomeres from oxidative damage and preserves telomeric DNA for extension by telomerase. Cell Rep 17: 3107-3114. doi:10.1016/j. celrep.2016.11.071

Ahn YH, Gibbons DL, Chakravarti D, Creighton CJ, Rizvi ZH, Adams HP, Pertsemlidis A, Gregory PA, Wright JA, Goodall GJ, et al (2012) ZEB1 drives prometastatic actin cytoskeletal remodeling by downregulating miR-34a expression. J Clin Invest 122: 3170-3183. doi:10.1172/jci63608

Arora R, Lee Y, Wischnewski H, Brun CM, Schwarz T, Azzalin CM (2014) RNaseH1 regulates TERRA-telomeric DNA hybrids and telomere maintenance in ALT tumour cells. Nat Commun 5: 5220. doi:10.1038/ncomms6220

Azzalin CM, Lingner J (2015) Telomere functions grounding on TERRA firma. Trends Cell Biol 25: 29-36. doi:10.1016/j.tcb.2014.08.007

Azzalin CM, Reichenbach P, Khoriauli L, Giulotto E, Lingner J (2007) Telomeric repeat containing RNA and RNA surveillance factors at mammalian chromosome ends. Science 318: 798-801. doi:10.1126/ science.1147182

Bagley BN, Keane TM, Maklakova VI, Marshall JG, Lester RA, Cancel MM, Paulsen AR, Bendzick LE, Been RA, Kogan SC, et al (2012) A dominantly acting murine allele of $\mathrm{Mcm} 4$ causes chromosomal abnormalities and promotes tumorigenesis. PLoS Genet 8: e1003034. doi:10.1371/journal. pgen.1003034

Balk B, Maicher A, Dees M, Klermund J, Luke-Glaser S, Bender K, Luke B (2013) Telomeric RNA-DNA hybrids affect telomere-length dynamics and senescence. Nat Struct Mol Biol 20: 1199-1205. doi:10.1038/nsmb.2662

Ballana E, Este JA (2015) SAMHD1: At the crossroads of cell proliferation, immune responses, and virus restriction. Trends Microbiol 23 680-692. doi:10.1016/j.tim.2015.08.002

Bao J, Wang S, Gunther LK, Kitajiri S, Li C, Sakamoto T (2015) The actinbundling protein TRIOBP- 4 and -5 promotes the motility of pancreatic cancer cells. Cancer Lett 356: 367-373. doi:10.1016/j.canlet.2014.08.005

Bartek J, Bartkova J, Lukas J (2007) DNA damage signalling guards against activated oncogenes and tumour progression. Oncogene 26: 7773-7779. doi:10.1038/sj.onc.1210881

Bartkova J, Rezaei N, Liontos M, Karakaidos P, Kletsas D, Issaeva N, Vassiliou LV, Kolettas E, Niforou K, Zoumpourlis VC, et al (2006) Oncogeneinduced senescence is part of the tumorigenesis barrier imposed by DNA damage checkpoints. Nature 444: 633-637. doi:10.1038/ nature05268

Bartocci C, Diedrich JK, Ouzounov I, Li J, Piunti A, Pasini D, Yates JR, 3rd, Lazzerini Denchi E (2014) Isolation of chromatin from dysfunctional telomeres reveals an important role for Ring1b in NHEJ-mediated chromosome fusions. Cell Rep 7: 1320-1332. doi:10.1016/j. celrep.2014.04.002

Bauer G (2012) Tumor cell-protective catalase as a novel target for rational therapeutic approaches based on specific intercellular ROS signaling. Anticancer Res 32: 2599-2624.

Bellon M, Datta A, Brown M, Pouliquen JF, Couppie P, Kazanji M, Nicot C (2006) Increased expression of telomere length regulating factors TRF1, TRF2 and TIN2 in patients with adult T-cell leukemia. Int I Cancer 119: 2090-2097. doi:10.1002/ijc.22026

Biroccio A, Cherfils-Vicini J, Augereau A, Pinte S, Bauwens S, Ye J, Simonet T, Horard B, Jamet K, Cervera L, et al (2013) TRF2 inhibits a cell-extrinsic pathway through which natural killer cells eliminate cancer cells. Nat Cell Biol 15: 818-828. doi:10.1038/ncb2774

Bodnar AG, Ouellette M, Frolkis M, Holt SE, Chiu C-P, Morin GB, Harley CB, Shay JW, Lichtsteinter S, Wright WE (1998) Extension of life-span by introduction of telomerase into normal human cells. Science 279: 349-352. doi:10.1126/science.279.5349.349

Brachner A, Foisner R (2014) Lamina-associated polypeptide (LAP)2alpha and other LEM proteins in cancer biology. Adv Exp Med Biol 773: 143-163. doi:10.1007/978-1-4899-8032-8_7

Calvete O, Martinez P, Garcia-Pavia P, Benitez-Buelga C, Paumard-Hernandez B, Fernandez V, Dominguez F, Salas C, Romero-Laorden N, GarciaDonas J, et al (2015) A mutation in the POT1 gene is responsible for cardiac angiosarcoma in TP53-negative Li-Fraumeni-like families. Nat Commun 6: 8383. doi:10.1038/ncomms9383 
Cesare AJ, Griffith JD (2004) Telomeric DNA in ALT cells is characterized by free telomeric circles and heterogeneous t-loops. Mol Cell Biol 24: 9948-9957. doi:10.1128/mcb.24.22.9948-9957.2004

Champeris Tsaniras S, Kanellakis N, Symeonidou IE, Nikolopoulou P, Lygerou Z, Taraviras S (2014) Licensing of DNA replication, cancer, pluripotency and differentiation: An interlinked world? Semin Cel Dev Biol 30: 174-180. doi:10.1016/j.semcdb.2014.03.013

Chang M, Arneric M, Lingner J (2007) Telomerase repeat addition processivity is increased at critically short telomeres in a Tel1-dependent manner in Saccharomyces cerevisiae. Genes Dev 21: 2485-2494. doi:10.1101/ gad. 1588807

Charest A, Lane K, McMahon K, Park J, Preisinger E, Conroy H, Housman D (2003) Fusion of FIG to the receptor tyrosine kinase ROS in a glioblastoma with an interstitial del(6)(q21q21). Genes Chromosomes Cancer 37: 58-71. doi:10.1002/gcc.10207

Chen SC, Hu TH, Huang CC, Kung ML, Chu TH, Yi LN, Huang ST, Chan HH, Chuang JH, Liu LF, et al (2015) Hepatoma-derived growth factor/nucleolin axis as a novel oncogenic pathway in liver carcinogenesis. Oncotarget 6 : 16253-16270. doi:10.18632/oncotarget.3608

Chen W, Wang Y, Li F, Lin W, Liang Y, Ma Z (2017) Expression of telomere repeat binding factor 1 and TRF2 in prostate cancer and correlation with clinical parameters. Biomed Research Int 2017: 9764752. doi:10.1155/ 2017/9764752

Chian CF, Hwang YT, Terng HJ, Lee SC, Chao TY, Chang H, Ho CL, Wu YY, Perng WC (2016) Panels of tumor-derived RNA markers in peripheral blood of patients with non-small cell lung cancer: Their dependence on age, gender and clinical stages. Oncotarget 7: 50582-50595. doi:10.18632/ oncotarget.10558

Clifford R, Louis T, Robbe P, Ackroyd S, Burns A, Timbs AT, Wright Colopy G, Dreau H, Sigaux F, Judde JG, et al (2014) SAMHD1 is mutated recurrently in chronic lymphocytic leukemia and is involved in response to DNA damage. Blood 123: 1021-1031. doi:10.1182/blood-2013-04-490847

Coker H, Brockdorff N (2014) SMCHD1 accumulates at DNA damage sites and facilitates the repair of DNA double-strand breaks. J Cell Sci 127: 1869-1874. doi:10.1242/jcs.140020

Coquel F, Silva MJ, Techer H, Zadorozhny K, Sharma S, Nieminuszczy J, Mettling C, Dardillac E, Barthe A, Schmitz AL, et al (2018) SAMHD1 acts at stalled replication forks to prevent interferon induction. Nature 557: 57-61. doi:10.1038/s41586-018-0050-1

Cox J, Mann M (2008) MaxQuant enables high peptide identification rates, individualized p.p.b.-range mass accuracies and proteome-wide protein quantification. Nat Biotechnol 26: 1367-1372. doi:10.1038/ nbt.1511

Cristofari G, Lingner J (2006) Telomere length homeostasis requires that telomerase levels are limiting. EMBO / 25: 565-574. doi:10.1038/sj. emboj.7600952

Cunha IW, Carvalho KC, Martins WK, Marques SM, Muto NH, Falzoni R, Rocha RM, Aguiar S, Simoes AC, Fahham L, et al (2010) Identification of genes associated with local aggressiveness and metastatic behavior in soft tissue tumors. Transl Oncol 3: 23-32. doi:10.1593/tlo.09166

d'Adda di Fagagna F, Reaper PM, Clay-Farrace L, Fiegler H, Carr P, Von Zglinicki T, Saretzki G, Carter NP, Jackson SP (2003) A DNA damage checkpoint response in telomere-initiated senescence. Nature 426: 194-198. doi:10.1038/nature02118

Daddacha W, Koyen AE, Bastien AJ, Head PE, Dhere VR, Nabeta GN, Connolly EC, Werner E, Madden MZ, Daly MB, et al (2017) SAMHD1 promotes DNA end resection to facilitate DNA repair by homologous recombination. Cell Rep 20: 1921-1935. doi:10.1016/j.celrep.2017.08.008

Dann SG, Golas J, Miranda M, Shi C, Wu J, Jin G, Rosfjord E, Upeslacis E, Klippel A (2014) p120 catenin is a key effector of a Ras-PKCvarepsilon oncogenic signaling axis. Oncogene 33: 1385-1394. doi:10.1038/onc.2013.91

Das M, Prasad SB, Yadav SS, Govardhan HB, Pandey LK, Singh S, Pradhan S, Narayan G (2013) Over expression of minichromosome maintenance genes is clinically correlated to cervical carcinogenesis. PLoS One 8: e69607. doi:10.1371/journal.pone.0069607

David-Watine B (2011) Silencing nuclear pore protein Tpr elicits a senescentlike phenotype in cancer cells. PloS one 6: e22423. doi:10.1371/journal. pone. 0022423

de Silva S, Wang F, Hake TS, Porcu P, Wong HK, Wu L (2014) Downregulation of SAMHD1 expression correlates with promoter DNA methylation in Sezary syndrome patients. I Invest Dermatol 134: 562-565. doi:10.1038/ jid.2013.311

Dejardin J, Kingston RE (2009) Purification of proteins associated with specific genomic Loci. Cell 136: 175-186. doi:10.1016/j.cell.2008.11.045

Denchi EL, de Lange T (2007) Protection of telomeres through independent control of ATM and ATR by TRF2 and POT1. Nature 448: 1068-1071. doi:10.1038/nature06065

Di Micco R, Fumagalli M, Cicalese A, Piccinin S, Gasparini P, Luise C, Schurra C, Garre M, Nuciforo PG, Bensimon A, et al (2006) Oncogene-induced senescence is a DNA damage response triggered by DNA hyperreplication. Nature 444: 638-642. doi:10.1038/nature05327

Diehl MC, Idowu MO, Kimmelshue KN, York TP, Jackson-Cook CK, Turner KC, Holt SE, Elmore LW (2011) Elevated TRF2 in advanced breast cancers with short telomeres. Breast Cancer Res Treat 127: 623-630. doi:10.1007/s10549-010-0988-7

Doksani Y, Wu JY, de Lange T, Zhuang X (2013) Super-resolution fluorescence imaging of telomeres reveals TRF2-dependent T-loop formation. Cell 155: 345-356. doi:10.1016/j.cell.2013.09.048

Drosopoulos WC, Kosiyatrakul ST, Schildkraut CL (2015) BLM helicase facilitates telomere replication during leading strand synthesis of telomeres. J Cell Biol 210: 191-208. doi:10.1083/jcb.201410061

Ducrest AL, Amacker M, Mathieu YD, Cuthbert AP, Trott DA, Newbold RF, Nabholz M, Lingner J (2001) Regulation of human telomerase activity: Repression by normal chromosome 3 abolishes nuclear telomerase reverse transcriptase transcripts but does not affect c-Myc activity. Cancer Res 61: 7594-7602.

Eeles RA, Kote-Jarai Z, Al Olama AA, Giles GG, Guy M, Severi G, Muir K, Hopper JL, Henderson BE, Haiman CA, et al (2009) Identification of seven new prostate cancer susceptibility loci through a genome-wide association study. Nat Genet 41: 1116-1121. doi:10.1038/ng.450

Feng XJ, Pan Q, Wang SM, Pan YC, Wang Q, Zhang HH, Zhu MH, Zhang SH (2016) MAP4K4 promotes epithelial-mesenchymal transition and metastasis in hepatocellular carcinoma. Tumour Biol 37: 11457-11467. doi:10.1007/ s13277-016-5022-1

Feretzaki M, Lingner J (2017) A practical qPCR approach to detect TERRA, the elusive telomeric repeat-containing RNA. Methods 114: 39-45. doi:10.1016/j.ymeth.2016.08.004

Fumagalli M, Rossiello F, Clerici M, Barozzi S, Cittaro D, Kaplunov JM, Bucci G, Dobreva M, Matti V, Beausejour CM, et al (2012) Telomeric DNA damage is irreparable and causes persistent DNA-damage-response activation. Nat Cell Biol 14: 355-365. doi:10.1038/ncb2466

Gao X, Chen G, Gao C, Zhang DH, Kuan SF, Stabile LP, Liu G, Hu J (2017) MAP4K4 is a novel MAPK/ERK pathway regulator required for lung adenocarcinoma maintenance. Mol Oncol 11: 628-639. doi:10.1002/ 1878-0261.12055

Glorieux C, Zamocky M, Sandoval JM, Verrax J, Calderon PB (2015) Regulation of catalase expression in healthy and cancerous cells. Free Radic Biol Med 87: 84-97. doi:10.1016/j.freeradbiomed.2015.06.017

Gorgoulis VG, Vassiliou LV, Karakaidos P, Zacharatos P, Kotsinas A, Liloglou T, Venere M, Ditullio RA, Jr, Kastrinakis NG, Levy B, et al (2005) Activation of the DNA damage checkpoint and genomic instability in human precancerous lesions. Nature 434: 907-913. doi:10.1038/nature03485

Gorman EB, Chen L, Albanese J, Ratech H (2007) Patterns of spectrin expression in B-cell lymphomas: Loss of spectrin isoforms is 
associated with nodule-forming and germinal center-related lymphomas. Mod Pathol 20: 1245-1252. doi:10.1038/modpathol.3800962

Graf M, Bonetti D, Lockhart A, Serhal K, Kellner V, Maicher A, Jolivet P, Teixeira MT, Luke B (2017) Telomere length determines TERRA and r-loop regulation through the cell cycle. Cell 170: 72-85 e14. doi:10.1016/j. cell.2017.06.006

Grinchuk OV, Motakis E, Kuznetsov VA (2010) Complex sense-antisense architecture of TNFAIP1/POLDIP2 on 17q11.2 represents a novel transcriptional structural-functional gene module involved in breast cancer progression. BMC Genomics 11 Suppl 1: S9. doi:10.1186/14712164-11-s1-s9

Grolimund L, Aeby E, Hamelin R, Armand F, Chiappe D, Moniatte M, Lingner J (2013) A quantitative telomeric chromatin isolation protocol identifies different telomeric states. Nat Commun 4: 2848. doi:10.1038/ ncomms3848

Haas DA, Bala K, Busche G, Weidner-Glunde M, Santag S, Kati S, Gramolelli S, Damas M, Dittrich-Breiholz O, Kracht M, et al (2013) The inflammatory kinase MAP4K4 promotes reactivation of Kaposi's sarcoma herpesvirus and enhances the invasiveness of infected endothelial cells. PLoS Pathog 9: e1003737. doi:10.1371/journal.ppat.1003737

Hahn WC, Counter CM, Lundberg AS, Beijersbergen RL, Brooks MW, Weinberg RA (1999) Creation of human tumour cells with defined genetic elements. Nature 400: 464-468. doi:10.1038/22780

Hahn WC, Dessain SK, Brooks MW, King JE, Elenbaas B, Sabatini DM, DeCaprio JA, Weinberg RA (2002) Enumeration of the simian virus 40 early region elements necessary for human cell transformation. Mol Cell Biol 22: 2111-2123. doi:10.1128/mcb.22.7.2111-2123.2002

Haiman CA, Han Y, Feng Y, Xia L, Hsu C, Sheng X, Pooler LC, Patel Y, Kolonel LN, Carter $\mathrm{E}$, et al (2013) Genome-wide testing of putative functional exonic variants in relationship with breast and prostate cancer risk in a multiethnic population. PLOS Genet 9: e1003419. doi:10.1371/journal. pgen.1003419

Halazonetis TD (2004) Constitutively active DNA damage checkpoint pathways as the driving force for the high frequency of p53 mutations in human cancer. DNA Repair 3: 1057-1062. doi:10.1016/j. dnarep.2004.03.036

Halazonetis TD, Gorgoulis VG, Bartek J (2008) An oncogene-induced DNA damage model for cancer development. Science 319: 1352-1355. doi:10.1126/science.1140735

Hamdi Y, Soucy P, Kuchenbaeker KB, Pastinen T, Droit A, Lemacon A, Adlard J, Aittomaki K, Andrulis IL, Arason A, et al (2017) Association of breast cancer risk in BRCA1 and BRCA2 mutation carriers with genetic variants showing differential allelic expression: Identification of a modifier of breast cancer risk at locus 11q22.3. Breast Cancer Res Treat 161: 117-134. doi:10.1007/s10549-016-4018-2

Harris CA, Andryuk PJ, Cline SW, Mathew S, Siekierka JJ, Goldstein G (1995) Structure and mapping of the human thymopoietin (TMPO) gene and relationship of human TMPO beta to rat lamin-associated polypeptide 2. Genomics 28: 198-205. doi:10.1006/geno.1995.1131

Hills SA, Diffley JF (2014) DNA replication and oncogene-induced replicative stress. Curr Biol 24: R435-R444. doi:10.1016/j.cub.2014.04.012

Hinrichsen I, Ernst BP, Nuber F, Passmann S, Schafer D, Steinke V, Friedrichs N, Plotz G, Zeuzem S, Brieger A (2014) Reduced migration of MLH1 deficient colon cancer cells depends on SPTAN1. Mol Cancer 13: 11. doi:10.1186/1476-4598-13-11

Hiraga SI, Ly T, Garzon J, Horejsi Z, Ohkubo YN, Endo A, Obuse C, Boulton SJ, Lamond Al, Donaldson AD (2017) Human RIF1 and protein phosphatase 1 stimulate DNA replication origin licensing but suppress origin activation. EMBO Rep 18: 403-419. doi:10.15252/ embr.201641983

Honeycutt KA, Chen Z, Koster MI, Miers M, Nuchtern J, Hicks J, Roop DR, Shohet JM (2006) Deregulated minichromosomal maintenance protein MCM7 contributes to oncogene driven tumorigenesis. Oncogene 25: 4027-4032. doi:10.1038/sj.onc.1209435

Horn S, Figl A, Rachakonda PS, Fischer C, Sucker A, Gast A, Kadel S, Moll I, Nagore E, Hemminki K, et al (2013) TERT promoter mutations in familial and sporadic melanoma. Science 339: 959-961. doi:10.1126/ science.1230062

Hu TH, Huang CC, Liu LF, Lin PR, Liu SY, Chang HW, Changchien CS, Lee CM Chuang JH, Tai MH (2003) Expression of hepatoma-derived growth factor in hepatocellular carcinoma. Cancer 98: 1444-1456. doi:10.1002/ cncr.11653

Hu Z, Zhang A, Storz G, Gottesman S, Leppla SH (2006) An antibody-based microarray assay for small RNA detection. Nucleic Acids Res 34: e52. doi:10.1093/nar/gkl142

Huang FW, Hodis E, Xu MJ, Kryukov GV, Chin L, Garraway LA (2013) Highly recurrent TERT promoter mutations in human melanoma. Science 339: 957-959. doi:10.1126/science.1229259

Hubbard K, Catalano J, Puri RK, Gnatt A (2008) Knockdown of TFIIS by RNA silencing inhibits cancer cell proliferation and induces apoptosis. BMC Cancer 8: 133. doi:10.1186/1471-2407-8-133

Jiang R, Yang ZH, Luo DH, Guo L, Sun R, Chen QY, Huang PY, Qiu F, Zou X, Cao KJ et al (2014) Elevated apolipoprotein A-I levels are associated with favorable prognosis in metastatic nasopharyngeal carcinoma. Med Oncol 31: 80. doi:10.1007/s12032-014-0080-y

Jiang X, Gillen S, Esposito I, Giese NA, Michalski CW, Friess H, Kleeff J (2010) Reduced expression of the membrane skeleton protein beta1spectrin (SPTBN1) is associated with worsened prognosis in pancreatic cancer. Histol Histopathol 25: 1497-1506. doi:10.14670/ HH25.1497

Jones RE, Oh S, Grimstead JW, Zimbric J, Roger L, Heppel NH, Ashelford KE, Liddiard K, Hendrickson EA, Baird DM (2014) Escape from telomeredriven crisis is DNA ligase III dependent. Cell Rep 8: 1063-1076. doi:10.1016/j.celrep.2014.07.007

Ju YT, Kwag SJ, Park HJ, Jung EJ, Jeong CY, Jeong SH, Lee YJ, Choi SK, Kang KR, Hah YS, et al (2015) Decreased expression of heat shock protein 20 in colorectal cancer and its implication in tumorigenesis. J Cell Biochem 116: 277-286. doi:10.1002/jcb.24966

Kaiser AM, Attardi LD (2017) Deconstructing networks of p53-mediated tumor suppression in vivo. Cell Death Differ 25: 93-103. doi:10.1038/ cdd.2017.171

Karami S, Han Y, Pande M, Cheng I, Rudd J, Pierce BL, Nutter EL, Schumacher FR, Kote-Jarai Z, Lindstrom S, et al (2016) Telomere structure and maintenance gene variants and risk of five cancer types. Int J Cancer 139: 2655-2670. doi:10.1002/ijc.30288

Kato T, Wada H, Patel P, Hu HP, Lee D, Ujiie H, Hirohashi K, Nakajima T, Sato M, Kaji M, et al (2016) Overexpression of KIF23 predicts clinical outcome in primary lung cancer patients. Lung Cancer 92: 53-61. doi:10.1016/j. lungcan.2015.11.018

Kim H, Lee OH, Xin H, Chen LY, Qin J, Chae HK, Lin SY, Safari A, Liu D, Songyang Z (2009) TRF2 functions as a protein hub and regulates telomere maintenance by recognizing specific peptide motifs. Nat Struct Mol Biol 16: 372-379. doi:10.1038/nsmb.1575

Kim NW, Piatyszek MA, Prowse KR, Harley CB, West MD, Ho PL, Coviello GM, Wright WE, Weinrich SL, Shay JW (1994) Specific association of human telomerase activity with immortal cells and cancer. Science 266: 2011-2015. doi:10.1126/science.7605428

Kim ST, Cheng Y, Hsu FC, Jin T, Kader AK, Zheng SL, Isaacs WB, Xu J, Sun J (2010) Prostate cancer risk-associated variants reported from genome-wide association studies: Meta-analysis and their contribution to genetic variation. Prostate 70: 1729-1738. doi:10.1002/pros.21208

Kourtidis A, Yanagisawa M, Huveldt D, Copland JA, Anastasiadis PZ (2015) Protumorigenic phosphorylation of p120 catenin in renal and breast cancer. PLoS One 10: e0129964. doi:10.1371/journal.pone.0129964 
Kwok HF, Zhang SD, McCrudden CM, Yuen HF, Ting KP, Wen Q, Khoo US, Chan KY (2015) Prognostic significance of minichromosome maintenance proteins in breast cancer. Am J Cancer Res 5: 52-71.

Laguette N, Sobhian B, Casartelli N, Ringeard M, Chable-Bessia C, Segeral E, Yatim A, Emiliani S, Schwartz O, Benkirane M (2011) SAMHD1 is the dendritic- and myeloid-cell-specific HIV-1 restriction factor counteracted by Vpx. Nature 474: 654-657. doi:10.1038/nature10117

Landsverk HB, Mora-Bermudez F, Landsverk OJ, Hasvold G, Naderi S, Bakke O, Ellenberg J, Collas P, Syljuasen RG, Kuntziger T (2010) The protein phosphatase 1 regulator PNUTS is a new component of the DNA damage response. EMBO Rep 11: 868-875. doi:10.1038/embor.2010.134

Lenain C, Bauwens S, Amiard S, Brunori M, Giraud-Panis MJ, Gilson E (2006) The Apollo 5' exonuclease functions together with TRF2 to protect telomeres from DNA repair. Curr Biol 16: 1303-1310. doi:10.1016/j. cub.2006.05.021

Li JP, Liu Y, Yin YH (2017) ARHGAP1 overexpression inhibits proliferation, migration and invasion of C-33A and SiHa cell lines. Onco Targets Ther 10: 691-701. doi:10.2147/ott.s112223

Li TF, Qin SH, Ruan XZ, Wang X (2015) p120-catenin participates in the progress of gastric cancer through regulating the Rac1 and Pak1 signaling pathway. Oncol Rep 34: 2357-2364. doi:10.3892/or.2015.4226

Lian J, Tang J, Shi H, Li H, Zhen T, Xie W, Zhang F, Yang Y, Han A (2015) Positive feedback loop of hepatoma-derived growth factor and beta-catenin promotes carcinogenesis of colorectal cancer. Oncotarget 6 : 29357-29374. doi:10.18632/oncotarget.4982

Liu YF, Qu GQ, Lu YM, Kong WM, Liu Y, Chen WX, Liao XH (2016) Silencing of MAP4K4 by short hairpin RNA suppresses proliferation, induces G1 cell cycle arrest and induces apoptosis in gastric cancer cells. Mol Med Rep 13: 41-48. doi:10.3892/mmr.2015.4510

Macari F, El-Houfi Y, Boldina G, Xu H, Khoury-Hanna S, Ollier J, Yazdani L, Zheng G, Bieche I, Legrand N, et al (2016) TRM6/61 connects PKCalpha with translational control through tRNAi(Met) stabilization: Impact on tumorigenesis. Oncogene 35: 1785-1796. doi:10.1038/onc.2015.244

Maciejowski J, de Lange T (2017) Telomeres in cancer: Tumour suppression and genome instability. Nat Rev Mol Cell Biol 18: 175-186. doi:10.1038/ nrm.2016.171

Majerska J, Redon S, Lingner J (2017) Quantitative telomeric chromatin isolation protocol for human cells. Methods 114: 28-38. doi:10.1016/j. ymeth.2016.08.003

Matsushima-Nishiwaki R, Adachi S, Yoshioka T, Yasuda E, Yamagishi Y, Matsuura J, Muko M, Iwamura R, Noda T, Toyoda H, et al (2011) Suppression by heat shock protein 20 of hepatocellular carcinoma cell proliferation via inhibition of the mitogen-activated protein kinases and AKT pathways. J Cell Biochem 112: 3430-3439. doi:10.1002/ jcb.23270

Matsushima-Nishiwaki R, Toyoda H, Nagasawa T, Yasuda E, Chiba N, Okuda S, Maeda A, Kaneoka Y, Kumada T, Kozawa O (2016) Phosphorylated heat shock protein 20 (HSPB6) regulates transforming growth factoralpha-induced migration and invasion of hepatocellular carcinoma cells. PLoS One 11: e0151907. doi:10.1371/journal.pone.0151907

Merati M, Buethe DJ, Cooper KD, Honda KS, Wang H, Gerstenblith MR (2015) Aggressive CD8(+) epidermotropic cutaneous T-cell lymphoma associated with homozygous mutation in SAMHD1. JAAD Case Rep 1: 227-229. doi:10.1016/j.jdcr.2015.05.003

Miller KM, Rog O, Cooper JP (2006) Semi-conservative DNA replication through telomeres requires Taz1. Nature 440: 824-828. doi:10.1038/ nature04638

Muller PA, Vousden KH (2013) p53 mutations in cancer. Nat Cell Biol 15: 2-8. doi:10.1038/ncb2641

Muller PA, Vousden KH, Norman JC (2011) p53 and its mutants in tumor cell migration and invasion. J Cell Biol 192: 209-218. doi:10.1083/ jcb.201009059
Munoz P, Blanco R, Blasco MA (2006) Role of the TRF2 telomeric protein in cancer and ageing. Cell Cycle 5: 718-721. doi:10.4161/cc.5.7.2636

Nagasawa T, Matsushima-Nishiwaki R, Toyoda H, Matsuura J, Kumada T, Kozawa O (2014) Heat shock protein 20 (HSPB6) regulates apoptosis in human hepatocellular carcinoma cells: Direct association with Bax. Oncol Rep 32: 1291-1295. doi:10.3892/or.2014.3278

Nakamura Y, Suzuki T, Arai Y, Sasano H (2009) 17beta-hydroxysteroid dehydrogenase type 11 (Pan1b) expression in human prostate cancer. Neoplasma 56: 317-320. doi:10.4149/neo_2009_04_317

Nakanishi K, Kawai T, Kumaki F, Hiroi S, Mukai M, Ikeda E, Koering CE, Gilson E (2003) Expression of mRNAs for telomeric repeat binding factor (TRF)1 and TRF2 in atypical adenomatous hyperplasia and adenocarcinoma of the lung. Clin Cancer Res 9: 1105-1111.

Natrajan R, Williams RD, Grigoriadis A, Mackay A, Fenwick K, Ashworth A, Dome JS, Grundy PE, Pritchard-Jones K, Jones C (2007) Delineation of a 1Mb breakpoint region at $1 \mathrm{p} 13$ in Wilms tumors by fine-tiling oligonucleotide array CGH. Genes Chromosomes Cancer 46: 607-615. doi:10.1002/gcc.20446

Naviaux RK, Costanzi E, Haas M, Verma IM (1996) The pCL vector system: Rapid production of helper-free, high-titer, recombinant retroviruses. J Virol 70: 5701-5705. 0022-538X/96/\$04.0010

Noda T, Kumada T, Takai S, Matsushima-Nishiwaki R, Yoshimi N, Yasuda E, Kato K, Toyoda H, Kaneoka Y, Yamaguchi A, et al (2007) Expression levels of heat shock protein 20 decrease in parallel with tumor progression in patients with hepatocellular carcinoma. Oncol Rep 17: 1309-1314. doi:10.3892/or.17.6.1309

Nozawa RS, Nagao K, Igami KT, Shibata S, Shirai N, Nozaki N, Sado T, Kimura H, Obuse C (2013) Human inactive X chromosome is compacted through a PRC2-independent SMCHD1-HBiX1 pathway. Nat Struct Mol Biol 20: 566-573. doi:10.1038/nsmb.2532

Ohara N, Haraguchi N, Koseki J, Nishizawa Y, Kawai K, Takahashi H, Nishimura J, Hata T, Mizushima T, Yamamoto $\mathrm{H}$, et al (2017) Low expression of the GOPC is a poor prognostic marker in colorectal cancer. Oncol Lett 14: 4483-4490. doi:10.3892/ol.2017.6817

Ong SE, Blagoev B, Kratchmarova I, Kristensen DB, Steen H, Pandey A, Mann M (2002) Stable isotope labeling by amino acids in cell culture, SILAC, as a simple and accurate approach to expression proteomics. Mol Cell Proteomics 1: 376-386. doi:10.1074/mcp.m200025-mcp200

Ono R, Matsuoka J, Yamatsuji T, Naomoto Y, Tanaka N, Matsui H, Matsushita M (2008) M-RIP, a novel target of JNK signaling and a requirement for human cancer cell invasion. Int J Mol Med 22: 199-203. doi:10.3892/ ijmm_00000009

Paeschke K, Capra JA, Zakian VA (2011) DNA replication through G-quadruplex motifs is promoted by the Saccharomyces cerevisiae Pif1 DNA helicase. Cell 145: 678-691. doi:10.1016/j.cell.2011.04.015

Pal D, Sharma U, Singh SK, Kakkar N, Prasad R (2015) Over-expression of telomere binding factors (TRF1 \& TRF2) in renal cell carcinoma and their inhibition by using SiRNA induce apoptosis, reduce cell proliferation and migration invitro. PLoS One 10: e0115651. doi:10.1371/ journal.pone. 0115651

Pasero P, Vindigni A (2017) Nucleases acting at stalled forks: How to reboot the replication program with a few shortcuts. Annu Rev Genet 51: 477-499. doi:10.1146/annurev-genet-120116-024745

Pfeiffer V, Crittin J, Grolimund L, Lingner J (2013) The THO complex component Thp2 counteracts telomeric R-loops and telomere shortening. EMBO J 32: 2861-2871. doi:10.1038/emboj.2013.217

Qiao N, Zhu Y, Li H, Qu Z, Xiao Z (2014) Expression of heat shock protein 20 inversely correlated with tumor progression in patients with ovarian cancer. Eur J Gynaecol Oncol 35: 576-579. doi:10.4028/www.scientific. net/amr.886.576

Qiu MH, Qian YM, Zhao XL, Wang SM, Feng XJ, Chen XF, Zhang SH (2012) Expression and prognostic significance of MAP4K4 in lung 
adenocarcinoma. Pathol Res Pract 208: 541-548. doi:10.1016/j prp.2012.06.001

Quesada V, Ramsay AJ, Rodriguez D, Puente XS, Campo E, Lopez-Otin C (2013) The genomic landscape of chronic lymphocytic leukemia: Clinical implications. BMC Med 11: 124. doi:10.1186/1741-7015-11-124

Ramsay AJ, Quesada V, Foronda M, Conde L, Martinez-Trillos A, Villamor N, Rodriguez D, Kwarciak A, Garabaya C, Gallardo M, et al (2013) POT1 mutations cause telomere dysfunction in chronic lymphocytic leukemia. Nat Genet 45: 526-530. doi:10.1038/ng.2584

Rentoft M, Lindell K, Tran P, Chabes AL, Buckland RJ, Watt DL, Marjavaara L, Nilsson AK, Melin B, Trygg J, et al (2016) Heterozygous colon cancerassociated mutations of SAMHD1 have functional significance. Proc Natl Acad Sci USA 113: 4723-4728. doi:10.1073/pnas.1519128113

Rhee I, Bachman KE, Park BH, Jair KW, Yen RW, Schuebel KE, Cui H, Feinberg AP, Lengauer C, Kinzler KW, et al (2002) DNMT1 and DNMT3b cooperate to silence genes in human cancer cells. Nature 416: 552-556. doi:10.1038/ 416552a

Robles-Espinoza CD, Harland M, Ramsay AJ, Aoude LG, Quesada V, Ding Z, Pooley KA, Pritchard AL, Tiffen JC, Petljak M, et al (2014) POT1 loss-offunction variants predispose to familial melanoma. Nat Genet 46: 478-481. doi:10.1038/ng.2947

Saarinen S, Aavikko M, Aittomaki K, Launonen V, Lehtonen R, Franssila K, Lehtonen HJ, Kaasinen E, Broderick P, Tarkkanen J, et al (2011) Exome sequencing reveals germline NPAT mutation as a candidate risk factor for Hodgkin lymphoma. Blood 118: 493-498. doi:10.1182/blood-201103-341560

Sagie S, Toubiana S, Hartono SR, Katzir H, Tzur-Gilat A, Havazelet S, Francastel C, Velasco G, Chedin F, Selig S (2017) Telomeres in ICF syndrome cells are vulnerable to DNA damage due to elevated DNA: RNA hybrids. Nat Commun 8: 14015. doi:10.1038/ncomms14015

Seo JH, Rivadeneira DB, Caino MC, Chae YC, Speicher DW, Tang HY, Vaira V, Bosari S, Palleschi A, Rampini P, et al (2016) The mitochondrial unfoldase-peptidase complex ClpXP controls bioenergetics stress and metastasis. PLoS Biol 14: e1002507. doi:10.1371/journal. pbio. 1002507

Sfeir A, Kosiyatrakul ST, Hockemeyer D, MacRae SL, Karlseder J, Schildkraut CL, de Lange T (2009) Mammalian telomeres resemble fragile sites and require TRF1 for efficient replication. Cell 138: 90-103. doi:10.1016/j. cell.2009.06.021

Shay JW, Wright WE (2005) Senescence and immortalization: Role of telomeres and telomerase. Carcinogenesis 26: 867-874. doi:10.1093/ carcin/bgh296

Shema E, Kim J, Roeder RG, Oren M (2011) RNF20 inhibits TFIIS-facilitated transcriptional elongation to suppress pro-oncogenic gene expression. Mol Cell 42: 477-488. doi:10.1016/j.molcel.2011.03.011

Shi L, Yang XM, Tang DD, Liu G, Yuan P, Yang Y, Chang LS, Zhang LR, Song DK (2015) Expression and significance of m1A transmethylase, hTrm6p/ hTrm61p and its related gene hTrm6/hTrm61 in bladder urothelial carcinoma. Am J Cancer Res 5: 2169-2179.

Shi Y, Lv G, Chu Z, Piao L, Liu X, Wang T, Jiang Y, Zhang P (2014) Identification of natural splice variants of SAMHD1 in virus-infected HCC. Oncol Rep 31: 687-692. doi:10.3892/or.2013.2895

Shima N, Alcaraz A, Liachko I, Buske TR, Andrews CA, Munroe RJ, Hartford SA, Tye BK, Schimenti JC (2007) A viable allele of Mcm4 causes chromosome instability and mammary adenocarcinomas in mice. Nat Genet 39: 93-98. doi:10.1038/ng1936

Soudet J, Jolivet P, Teixeira MT (2014) Elucidation of the DNA end-replication problem in Saccharomyces cerevisiae. Mol Cell 53: 954-964. doi:10.1016/j.molcel.2014.02.030

Su F, Kozak KR, Imaizumi S, Gao F, Amneus MW, Grijalva V, Ng C, Wagner A, Hough G, Farias-Eisner G, et al (2010) Apolipoprotein A-I (apoA-I) and apoA-I mimetic peptides inhibit tumor development in a mouse model of ovarian cancer. Proc Natl Acad Sci USA 107: 19997-20002 doi:10.1073/pnas.1009010107

Sun L, Zhang C, Yang Z, Wu Y, Wang H, Bao Z, Jiang T (2016) KIF23 is an independent prognostic biomarker in glioma, transcriptionally regulated by TCF-4. Oncotarget 7: 24646-24655. doi:10.18632/ oncotarget.8261

Sun X, Jin Z, Song X, Wang J, Li Y, Qian X, Zhang Y, Yin Y (2015) Evaluation of KIF23 variant 1 expression and relevance as a novel prognostic factor in patients with hepatocellular carcinoma. BMC Cancer 15: 961. doi:10.1186/s12885-015-1987-1

Suram A, Kaplunov J, Patel PL, Ruan H, Cerutti A, Boccardi V, Fumagalli M, Di Micco R, Mirani N, Gurung RL, et al (2012) Oncogene-induced telomere dysfunction enforces cellular senescence in human cancer precursor lesions. EMBO J 31: 2839-2851. doi:10.1038/emboj.2012.132

Takahashi S, Fusaki N, Ohta S, Iwahori Y, lizuka Y, Inagawa K, Kawakami Y, Yoshida K, Toda M (2012) Downregulation of KIF23 suppresses glioma proliferation. J Neurooncol 106: 519-529. doi:10.1007/s11060-011-0706-2

Tang M, Li Y, Zhang X, Deng T, Zhou Z, Ma W, Songyang Z (2014) Structural maintenance of chromosomes flexible hinge domain containing 1 (SMCHD1) promotes non-homologous end joining and inhibits homologous recombination repair upon DNA damage. J Biol Chem 289: 34024-34032. doi:10.1074/jbc.m114.601179

Thoreson MA, Reynolds AB (2002) Altered expression of the catenin p120 in human cancer: Implications for tumor progression. Differ Res Biol Divers 70: 583-589. doi:10.1046/j.1432-0436.2002.700911.x

Thutkawkorapin J, Picelli S, Kontham V, Liu T, Nilsson D, Lindblom A (2016) Exome sequencing in one family with gastric- and rectal cancer. BMC Genet 17: 41. doi:10.1186/s12863-016-0351-z

Tuominen H, Sormunen R, Kallioinen M (1996) Non-erythroid spectrin (fodrin) in cutaneous tumours: Diminished in cell membranes, increased in the cytoplasm. Br J Dermatol 135: 576-580. doi:10.1111/ j.1365-2133.1996.tb03834.X

van Duijnhoven FJ, Bueno-De-Mesquita HB, Calligaro $M$, Jenab M, Pischon $T$ Jansen EH, Frohlich J, Ayyobi A, Overvad K, Toft-Petersen AP, et al (2011) Blood lipid and lipoprotein concentrations and colorectal cancer risk in the European Prospective Investigation into Cancer and Nutrition. Gut 60: 1094-1102. doi:10.1136/gut.2010.225011

van Overbeek M, de Lange T (2006) Apollo, an Artemis-related nuclease, interacts with TRF2 and protects human telomeres in S phase. Curr Biol 16: 1295-1302. doi:10.1016/j.cub.2006.05.022

Vannier JB, Pavicic-Kaltenbrunner V, Petalcorin MI, Ding H, Boulton SJ (2012) RTEL1 dismantles T loops and counteracts telomeric G4-DNA to maintain telomere integrity. Cell 149: 795-806. doi:10.1016/j. cell.2012.03.030

Vizcaino JA, Csordas A, del-Toro N, Dianes JA, Griss J, Lavidas I, Mayer G, PerezRiverol Y, Reisinger F, Ternent T, et al (2016) 2016 update of the PRIDE database and its related tools. Nucleic Acids Res 44: D447-D456. doi:10.1093/nar/gkv1145

Wang CD, Sun Y, Chen N, Huang L, Huang JW, Zhu M, Wang T, Ji YL (2016) The role of catalase C262T gene polymorphism in the susceptibility and survival of cancers. Scientific Rep 6: 26973. doi:10.1038/srep26973

Wang JL, Lu FZ, Shen XY, Wu Y, Zhao LT (2014) SAMHD1 is down regulated in lung cancer by methylation and inhibits tumor cell proliferation. Biochem Biophys Res Commun 455: 229-233. doi:10.1016/j. bbrc.2014.10.153

Wang X, Dai S, Zhang Z, Liu L, Wang J, Xiao X, He D, Liu B (2009) Characterization of apolipoprotein A-I as a potential biomarker for cholangiocarcinoma. Eur J Cancer Care 18: 625-635. doi:10.1111/j.13652354.2008.00965.x

Wolgast LR, Cannizzarro LA, Ramesh KH, Xue X, Wang D, Bhattacharyya PK, Gong JZ, MCMahon C, Albanese JM, Sunkara JL, et al. (2011) Spectrin isoforms: Differential expression in normal hematopoiesis and 
alterations in neoplastic bone marrow disorders. Am J Clin Pathol 136: 300-308. doi:10.1309/ajcpsa5rnm9igfjf

Wu D, Niu X, Pan H, Zhang Z, Zhou Y, Qu P, Zhou J (2016) MicroRNA-497 targets hepatoma-derived growth factor and suppresses human prostate cancer cell motility. Mol Med Rep 13: 2287-2292. doi:10.3892/ mmr.2016.4756

Wu P, Takai H, de Lange T (2012) Telomeric 3' overhangs derive from resection by Exo1 and apollo and fill-in by POT1b-associated CST. Cell 150:39-52. doi:10.1016/j.cell.2012.05.026

Yang CS, Jividen K, Spencer A, Dworak N, Ni L, Oostdyk LT, Chatterjee M, Kusmider B, Reon B, Parlak M, et al (2017) Ubiquitin modification by the E3 ligase/ADP-ribosyltransferase Dtx3L/Parp9. Mol Cell 66: 503-516.e5. doi:10.1016/j.molcel.2017.04.028

Yang GY, Zhang AQ, Wang J, Li CH, Wang XQ, Pan K, Zhou C, Dong JH (2016) Hepatoma-derived growth factor promotes growth and metastasis of hepatocellular carcinoma cells. Cell Biochem Funct 34: 274-285. doi:10.1002/cbf.3189

Yao ZX, Jogunoori W, Choufani S, Rashid A, Blake T, Yao W, Kreishman P, Amin R, Sidawy AA, Evans SR, et al (2010) Epigenetic silencing of betaspectrin, a TGF-beta signaling/scaffolding protein in a human cancer stem cell disorder: Beckwith-Wiedemann syndrome. J Biol Chem 285: 36112-36120. doi:10.1074/jbc.m110.162347

Ye J, Lenain C, Bauwens S, Rizzo A, Saint-Leger A, Poulet A, Benarroch D, Magdinier F, Morere J, Amiard S, et al (2010) TRF2 and apollo cooperate with topoisomerase 2alpha to protect human telomeres from replicative damage. Cell 142: 230-242. doi:10.1016/j.cell.2010.05.032
Zamanian-Daryoush M, DiDonato JA (2015) Apolipoprotein A-I and cancer. Front Pharmacol 6: 265. doi:10.3389/fphar.2015.00265

Zellinger B, Akimcheva S, Puizina J, Schirato M, Riha K (2007) Ku suppresses formation of telomeric circles and alternative telomere lengthening in Arabidopsis. Mol Cell 27: 163-169. doi:10.1016/j.molcel.2007.05.025

Zhang L, Wang G, Chen S, Ding J, Ju S, Cao H, Tian H (2016) Depletion of thymopoietin inhibits proliferation and induces cell cycle arrest/ apoptosis in glioblastoma cells. World I Surg Oncol 14: 267. doi:10.1186/s12957-016-1018-y

Zhao J, Kennedy BK, Lawrence BD, Barbie DA, Matera AG, Fletcher JA, Harlow E (2000) NPAT links cyclin E-Cdk2 to the regulation of replicationdependent histone gene transcription. Genes Dev 14: 2283-2297. doi:10.1101/gad.827700

Zhi X, Lin L, Yang S, Bhuvaneshwar K, Wang H, Gusev Y, Lee MH, Kallakury B, Shivapurkar N, Cahn K, et al (2015) betall-Spectrin (SPTBN1) suppresses progression of hepatocellular carcinoma and Wnt signaling by regulation of Wnt inhibitor kallistatin. Hepatology 61: 598-612. doi:10.1002/hep.27558

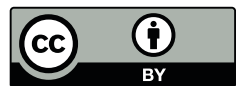

License: This article is available under a Creative Commons License (Attribution 4.0 International, as described at https://creativecommons.org/ licenses/by/4.0/). 